Check for updates

Cite this: RSC Adv., 2021, 11, 38172

Received 24th September 2021 Accepted 22nd November 2021

DOI: $10.1039 / d 1 r a 07159 a$

rsc.li/rsc-advances

\section{Rapid antibacterial activity of anodized aluminum- based materials impregnated with quaternary ammonium compounds for high-touch surfaces to limit transmission of pathogenic bacteria†}

\author{
Jessica Jann, (D) abe Olivier Drevelle, ${ }^{a}$ X. Grant Chen, ${ }^{c}$ Myriam Auclair-Gilbert, ${ }^{d}$ \\ Gervais Soucy, (D) ${ }^{a}$ Nathalie Faucheux ${ }^{* a b}$ and Louis-Charles Fortier (D)
}

\begin{abstract}
Infections caused by multidrug-resistant bacteria are a major public health problem. Their transmission is strongly linked to cross contamination via inert surfaces, which can serve as reservoirs for pathogenic microorganisms. To address this problem, antibacterial materials applied to high-touch surfaces have been developed. However, reaching a rapid and lasting effectiveness under real life conditions of use remains challenging. In the present paper, hard-anodized aluminum (AA) materials impregnated with antibacterial agents (quaternary ammonium compounds (QACs) and/or nitrate silver $\left(\mathrm{AgNO}_{3}\right)$ ) were prepared and characterized. The thickness of the anodized layer was about $50 \mu \mathrm{m}$ with pore diameter of $70 \mathrm{~nm}$. AA with QACs and/or $\mathrm{AgNO}_{3}$ had a water contact angle varying between 45 and $70^{\circ}$. The antibacterial activity of the materials was determined under different experimental settings to better mimic their use, and included liquid, humid, and dry conditions. AA-QAC surfaces demonstrated excellent efficiency, killing $>99.9 \%$ of bacteria in $5 \mathrm{~min}$ on a wide range of Gram-positive (Staphylococcus aureus, Clostridioides difficile, vancomycin-resistant Enterococcus faecium) and Gramnegative (streptomycin-resistant Salmonella typhimurium and encapsulated Klebsiella pneumoniae) pathogens. AA-QACs showed a faster antibacterial activity (from 0.25 to $5 \mathrm{~min}$ ) compared with antibacterial copper used as a reference (from $15 \mathrm{~min}$ to more than $1 \mathrm{~h}$ ). We show that to maintain their high performance, AA-QACs should be used in low humidity environments and should be cleaned with solutions composed of QACs. Altogether, AA-QAC materials constitute promising candidates to prevent the transmission of pathogenic bacteria on high-touch surfaces.
\end{abstract}

\section{Introduction}

Bacterial nosocomial infections represent an extremely serious global threat to human health. ${ }^{1-3}$ Drug-resistant infections are currently responsible for 700000 deaths per year worldwide and if the current situation does not improve, this human toll might reach 10 million deaths per year by $2050 .^{3}$ The direct (healthcare) and indirect (international trade, animal production)

\footnotetext{
${ }^{a}$ Department of Chemical and Biotechnological Engineering, Faculty of Engineering, Université de Sherbrooke, 2500 boul. de l'Université, Sherbrooke, Québec, J1K 2R1, Canada.E-mail: Nathalie.Faucheux@USherbrooke.ca

${ }^{b}$ Clinical Research Center of Centre Hospitalier Universitaire de Sherbrooke, $12 \mathrm{e}$ Avenue N, Sherbrooke, Québec, J1H 5N4, Canada

${ }^{c}$ Department of Applied Science, University of Quebec in Chicoutimi, Saguenay, Quebec, G7H 2B1, Canada

${ }^{d}$ A3 Surfaces, 1433, Rue de la Manic, Chicoutimi, Québec, G7K 1G8, Canada

${ }^{e}$ Department of Microbiology and Infectious Diseases, Faculty of Medicine and Health Sciences, Université de Sherbrooke, 3201 rue Jean Mignault, Sherbrooke, Québec, J1E 4K8, Canada. E-mail: Louis-Charles.Fortier@USherbrooke.ca

$\dagger$ Electronic supplementary information (ESI) available. See DOI: 10.1039/d1ra07159a
}

impacts of these infections also place a heavy financial burden on global systems, estimated between 1.0 and $3.4 \mathrm{~S}$ billion per year. ${ }^{4,5}$ Finding new drugs to fight bacterial pathogens is urgent but developing new strategies to break the transmission chain and prevent propagation of these bacteria is also crucial.

The transmission of bacterial pathogens that cause infections is mainly linked to cross-contamination through inert surfaces and the environment. ${ }^{\mathbf{1 , 6 - 8}}$ An interesting way to limit the spread of pathogenic bacteria, without the use of antibiotics, is to develop antibacterial materials for use in high contact areas, such as door handles, stair railings, components of public transport and other surfaces that can serve as reservoirs for microorganisms..$^{8-10}$

Several strategies can be used to design antibacterial materials. One of them is to select a type of material with inherent antibacterial activity such as metal alloys, mainly based on copper, silver, or zinc..$^{10-13}$ Copper-based alloys are currently the most used with over 500 materials registered as antibacterial products by the U.S. Environmental Protection Agency (EPA). They are capable of killing $99.9 \%$ of pathogenic bacteria within 2 h. ${ }^{14-16}$ However, 
several issues have been raised with copper-based alloys, such as durability, corrosion susceptibility, bacterial resistance selection and cost-effectiveness. ${ }^{17}$ In addition, their effectiveness to prevent cross-contamination or to reduce the incidence of healthcareassociated infections (HAI) was not based on blinded, randomized and unbiased clinical studies. ${ }^{18-21}$

Another strategy consists in applying specific coatings to acquire antibacterial surface properties (superhydrophobicity, nanostructuring) or to incorporate into the material a wide variety of known antibacterial compounds (copper, silver, quaternary ammoniums compounds (QACs), etc.). ${ }^{\mathbf{1 0 1 2 , 2 2 - 2 8}}$ QACs are antimicrobial agents effective against a broad spectrum of Gram-positive and Gram-negative bacteria as well as several enveloped viruses, and they are widely used in cleaning products. $^{29,30}$ The persistence of their antibacterial property over time and over a wide $\mathrm{pH}$ range, their odorless and amphiphilic properties, as well as the low cost of commercial grade QACs make them very good candidates for manufacturing biocidal surfaces. ${ }^{31-33}$ The silver ions, due to their antibacterial effect mediated by interactions and alterations of proteins and cell walls, are also used in various applications such as medical devices (central venous catheters and topical antiseptics: silver nitrate and silver sulfadiazine), textiles (clothing and bedsheets) and self-disinfecting surfaces (Surfacine ${ }^{\mathrm{TM}}$ ).,12,34,35

Proper testing of antibacterial surfaces is critical to evaluate their effectiveness. Several international standards are currently used to assess the antibacterial properties of materials such as the Japanese standard (JIS Z2801: 2010), the European standard (ISO 22196: 2011), the American interim standard (US EPA: 2020) and its older standard more specific to copper surfaces (US EPA: 2015). These standards recommend testing antibacterial activity on model pathogens like Staphylococcus aureus and Escherichia coli (JIS Z2801 and ISO 22196) or Pseudomonas aeruginosa (US EPA). However, the antibacterial properties of materials are usually evaluated after long contact times such as 1-2 h to several days (e.g., 99.9\% of bacteria killed within 1-2 h: EPA) under liquid conditions, not representative of the practical conditions of high touch surfaces.

In the present study, we report antibacterial activity testing of anodized aluminum-based surfaces that aim to limit the spread of pathogenic bacteria. ${ }^{36}$ The low cost of aluminum (4 times cheaper than copper) and the anodizing process, as well as its wide range of applications (industrial, commercial and consumer goods) make anodized aluminum-based materials very interesting candidates for use in high-touch surfaces. ${ }^{37}$

The antibacterial materials consist of a nanoporous surface layer impregnated with antibacterial solutions. First, the aluminum-based materials were characterized after the anodization and impregnation steps by scanning electron microscopy (SEM) and contact angle measurement. The release kinetics of the impregnated compounds were also evaluated by inductively coupled plasma optical emission spectrometry (ICPOES) and UV spectrophotometry. The antibacterial properties of the solutions selected for impregnation of the anodized aluminum $\left(\mathrm{AgNO}_{3}\right.$ and/or QACs) were verified on Gram-positive and Gram-negative bacterial pathogens posing significant clinical problems in hospitals: Staphylococcus aureus,
Clostridioides difficile, vancomycin-resistant enterococci, Escherichia coli, streptomycin-resistant Salmonella and Klebsiella pneumoniae. Then, the antibacterial properties of these materials were determined in a time dependent manner using experimental approaches that we developed to better mimic real life conditions of use of these materials. Copper was used as an antibacterial effectiveness control. Finally, we evaluated the antibacterial properties and tested the durability of the materials after treatment with different cleaning products and after repeated immersions into water.

\section{Experimental section}

\subsection{Materials}

2.1.1. Surface materials. The materials used are hardanodized aluminum surfaces (AA6061 and AA5052 alloys) impregnated with different antibacterial solutions: (i) $\mathrm{AgNO}_{3}$ $(1 \% \mathrm{w} / \mathrm{v})$; (ii) QACs-based $(10.9 \% \mathrm{w} / \mathrm{v})$ solution containing alkyldimethylbenzylammonium chloride (ADBAC), octyldecyldimethylammonium chloride, dioctyldimethylammonium chloride and didecyldimethylammonium chloride (DDAC); (iii) a combination of both $\mathrm{AgNO}_{3}(1 \% \mathrm{w} / \mathrm{v})$ and QACs-based $(10.9 \%$ $\mathrm{w} / \mathrm{v}$ ) solutions (Fig. S1†). This technology is patented by the company A3S (A3Surfaces, Chicoutimi, Quebec, Canada), ${ }^{38}$ who produced all anodized aluminum-based materials used in the present study. In all assays, aluminum without anodization (Al) and anodized aluminum without antibacterial solution impregnation (AA) were used as negative controls. Copper alloy C70600 (common name: CuNi10Fe1Mn) was also used as an antibacterial material control. ${ }^{39}$

2.1.2. Bacterial strains and culture media. The selected bacterial strains which represent the vast majority of problematic nosocomial and community infections nowadays and their characteristics are listed in Table S1. $\uparrow^{3,4}$ Staphylococcus aureus (ATCC® 29213 ${ }^{\mathrm{TM}}$ ) and Escherichia coli (ATCC® 29532 ${ }^{\mathrm{TM}}$ ) were purchased from ATCC ${ }^{\circledR}$ (Manassas, VA, USA). Clostridioides difficile epidemic strain R20291 and streptomycin-resistant Salmonella enterica serovar Typhimurium SL1344 were kindly provided by Dr Trevor Lawley (Sanger Institute, United Kingdom) and the laboratory of Pr. Alfredo Menendez (Université de Sherbrooke, QC, Canada), ${ }^{40}$ respectively. Klebsiella pneumoniae, vancomycin-resistant Enterococcus faecalis (Van B) and vancomycin-resistant Enterococcus faecium (Van A) were clinical isolates obtained from the Centre Hospitalier Universitaire de Sherbrooke (CHUS), thanks to Dr Simon Lévesque (Sherbrooke, QC, Canada). Brain Heart Infusion (BHI), Tryptose-Yeast extract (TY: $3 \%$ tryptose and 2\% yeast extract, $\mathrm{pH}$ 7.4), Luria-Bertani (LB), and Mueller-Hinton ( $\mathrm{MH}$ ) broths were purchased from BD Biosciences (Mississauga, ON, Canada). For solid media, $1 \%(\mathrm{w} / \mathrm{v})$ agar was added to the above media.

\subsection{Methods}

2.2.1. Surface wettability. The sessile drop method was performed to measure static contact angle on aluminum and copper materials using a goniometer coupled to a camera system (First Ten Angstroms, FTA 200). Drops of distilled water 
controlled at $1 \mu \mathrm{L}$ were deposited on the surfaces using a microliter syringe. All steps, from the material placement to wettability measurements using the ellipse-tangent fit method, were automated and controlled by computer via FTA32Video software. Four measurements were taken at different locations on both sides of each sample at room temperature allowing consistent assessment of the materials.

2.2.2. Characterization of the anodization layer. A cross section was made on the materials using a cutter with diamond blades from Buehler (Esslingen, Germany). Then, the materials were held vertically in a resin (EpoxyCure ${ }^{\mathrm{TM}} 2$, Buehler, IL, USA) to be able to observe their cross sections. A polishing (from 1 $\mu \mathrm{m}$ to $0.05 \mu \mathrm{m}$ ) and a metallization step with a gold/palladium mixture were then carried out. Subsequently, the slices of materials were observed by scanning electron microscopy at a voltage of $5.0 \mathrm{kV}$ (Hitachi SU8000, Japan).

2.2.3. QACs release kinetics from anodized aluminum materials with or without impregnation. Material samples (disks of $1 \mathrm{~cm}$ in diameter) consisting of $\mathrm{AA}, \mathrm{AA}-\mathrm{AgNO}_{3}, \mathrm{AA}-$ QACs and $\mathrm{AA}-\mathrm{AgNO}_{3}-\mathrm{QACs}$ were immersed in $1 \mathrm{~mL}$ of nanopure water for a predetermined duration ranging from $30 \mathrm{~s}$ to $144 \mathrm{~h}$. At each time point, the solution was collected, and the absorbance was measured at a wavelength of $215 \mathrm{~nm}$ using a UV-VIS spectrophotometer (Ultrospec 2100 pro UV-VIS Spectrophotometer, Amersham Biosciences, UK). Calibration curves obtained by measuring the absorbance at $215 \mathrm{~nm}$ of several dilutions of the QACs stock solution showed linear behavior and were used to calculate the concentrations of QACs released from the materials.

2.2.4. Bacteria culture. Frozen stocks of bacterial strains stored at $-80{ }^{\circ} \mathrm{C}$ in glycerol were spread out on agar plates and grown overnight under the appropriate conditions (see Table $\mathrm{S} 1 \dagger)$. For $C$. difficile experiments, bacteria were manipulated and incubated under anaerobic conditions (10\% hydrogen, $5 \% \mathrm{CO}_{2}$ and $85 \%$ nitrogen) using an anaerobic chamber (Coy Laboratories, Grass Lake, MI, USA), and all media were pre-reduced overnight $(\mathrm{O} / \mathrm{N})$ before use. Prior to each experiment, bacterial pre-cultures inoculated from a single isolated colony were prepared in $5 \mathrm{~mL}$ of broth and incubated $\mathrm{O} / \mathrm{N}$ at $37^{\circ} \mathrm{C}$. Then, at their logarithmic stage of growth, bacterial cells were diluted in fresh broth and the optical density at $600 \mathrm{~nm}\left(\mathrm{OD}_{600}\right)$ was determined using a portable spectrophotometer (Fisherbrand $^{\text {TM }}$ Cell Density Meter 40, ThermoFisher Scientific, USA) to adjust the working bacterial density.

2.2.5. Minimal inhibitory concentration (MIC) and minimal bactericidal concentration (MBC) assay. The minimum inhibitory concentration (MIC) and minimum bactericidal concentration (MBC) of each solution used for the impregnation of materials $\left(\mathrm{AgNO}_{3}, \mathrm{QACs}\right.$ and $\mathrm{AgNO}_{3}+\mathrm{QACs}$ solution) were evaluated on each bacterial strain under study. To determine the MIC, doubling dilutions of the solutions to be tested were prepared in 96-well microtiter plates. An inoculum of $100 \mu \mathrm{L}$ of bacterial suspension $\left(10^{6}\right.$ colony forming units (CFU) per $\mathrm{mL}$ ) prepared as mentioned above, was added to each well containing $100 \mu \mathrm{L}$ of antibacterial solution. Negative controls without bacterial culture and positive controls without antibacterial solution were used in parallel. The plates were incubated for $18 \mathrm{~h}$ at $37^{\circ} \mathrm{C}$ and the $\mathrm{OD}_{600}$ was measured using a UV-VIS spectrophotometer (Synergy ${ }^{\mathrm{TM}}$ HTX Multi-Mode Microplate Reader, BioTek, USA). The lowest concentration of each impregnation solution at which no turbidity could be observed was defined as the MIC. To determine the MBC, 100 $\mu \mathrm{L}$ from each well of MIC plates showing no bacteria growth were transferred in 96-well microtiter plates to make decimal dilutions using fresh sterile broth. Subsequently, $20 \mu \mathrm{L}$ aliquots were spotted on agar plates (spot plating assay ${ }^{\mathbf{4 1 , 4 2}}$ ) and colonies were counted after $24 \mathrm{~h}$ of incubation at $37{ }^{\circ} \mathrm{C}$. The lowest concentration of antibacterial solution for which no colony could be observed was defined to be MBC.

2.2.6. Antibacterial activity of materials using a swab liquid-inoculation assay. A swab liquid-inoculation assay was carried out to evaluate the antibacterial activity of materials (Fig. 1A). A sterile nylon swab (FLOQSwabs ${ }^{\mathrm{TM}}$, Copan, Italy) was immersed in a bacterial suspension $\left(10^{8} \mathrm{CFU} \mathrm{mL}^{-1}\right)$ prepared as mentioned above and the excess liquid was drained. The contaminated swab was rubbed on the material sample for $5 \mathrm{~s}$, allowing for standardized inoculation of $10^{6} \mathrm{CFU}$ per surface. Following a contact kinetics of $0.25,1,5,15$ and $60 \mathrm{~min}$, the contaminated materials were immersed into $1 \mathrm{~mL}$ of QACs neutralization solution Casein peptone Lecithin Polysorbate Broth $^{\mathbf{4 3 4 4}}$ (Sigma-Aldrich®, MO, USA) containing $0.04 \%$ of Tween20® (Bioshop ${ }^{\circledR}$, ON, Canada), and vortexed for $10 \mathrm{~s}$. This neutralization solution did not affect the viability of bacteria. Aliquots of bacteria released from the contaminated materials in the neutralization solution were immediately transferred to a 96-well plate, serially diluted in sterile broth, and spotted on agar plates using a spot plating assay as described above. The number of $\mathrm{CFU}$ were counted after $\mathrm{O} / \mathrm{N}$ incubation at $37{ }^{\circ} \mathrm{C}$ to determine the bacterial load present on the materials.

2.2.7. Antibacterial activity of materials using a humidtransfer inoculation assay. A humid-transfer inoculation assay was carried out to evaluate the effectiveness of materials to prevent bacterial cross-contamination under limited water content (Fig. 1B). A $10 \mu \mathrm{L}$ inoculum of a bacterial suspension

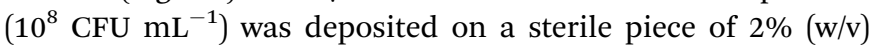
agarose gel $(1 \mathrm{~cm} \times 1 \mathrm{~cm})$ and left for $1 \mathrm{~h}$ under the biological hood to obtain a final relative humidity (RH) of $89.4 \pm 0.9 \%$. The RH of the gel was measured by the drying technique in an oven maintained at $160{ }^{\circ} \mathrm{C}$, by means of weighing the gel before and after drying (considered dry when its weight was constant in the oven). To evaluate the level of contamination of the materials resulting from the transfer of bacteria from the gel, the different materials were deposited on the contaminated gels for $0.25,1,5,15$ and $60 \mathrm{~min}$ and then the number of surviving bacteria on the materials was determined as described above. In parallel, to determine the effect of a contact with antibacterial materials on the bacteria present in the contaminated gel, the pieces of gel were transferred in $2 \mathrm{~mL}$ microtubes containing $1 \mathrm{~mL}$ of neutralization solution and four sterile $3 \mathrm{~mm}$ glass beads. The pieces of gel were then disrupted and homogenized for $10 \mathrm{~min}$ at $30 \mathrm{~s}^{-1}$ frequency using a Mixer Mill MM 400 (Retsch®, France) to release bacteria trapped in the gel, which were then quantified by spot plating assay as described above. CFUs were counted to determine the number of surviving 


\section{A. Swab liquid-inoculation assay}

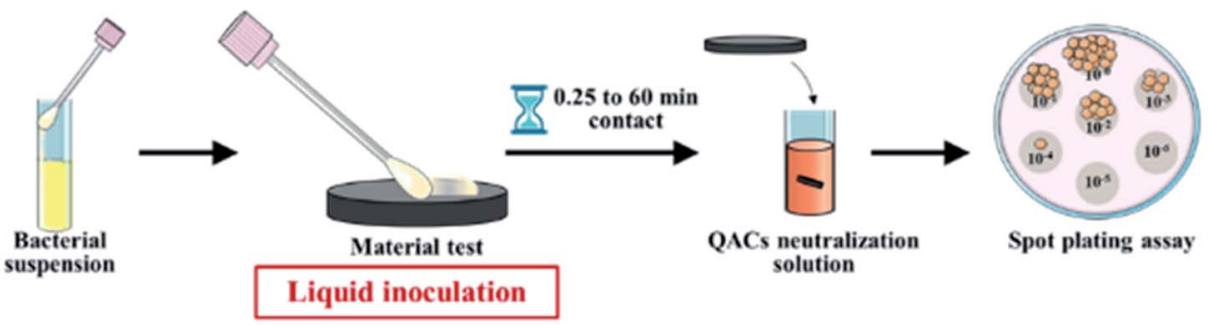

B. Humid-transfer inoculation assay

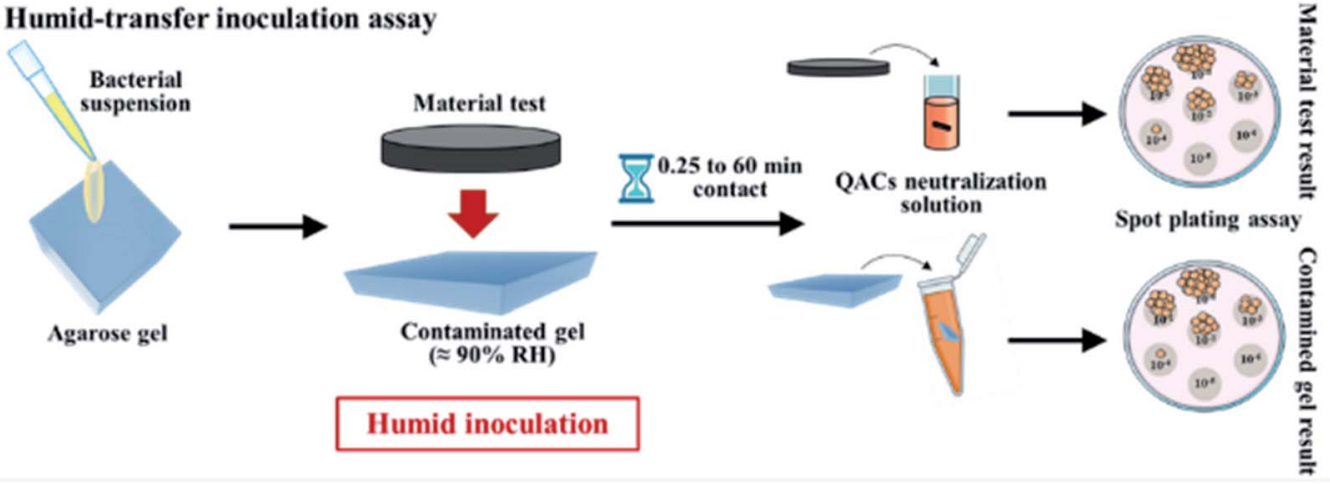

C. Dry-transfer inoculation assay

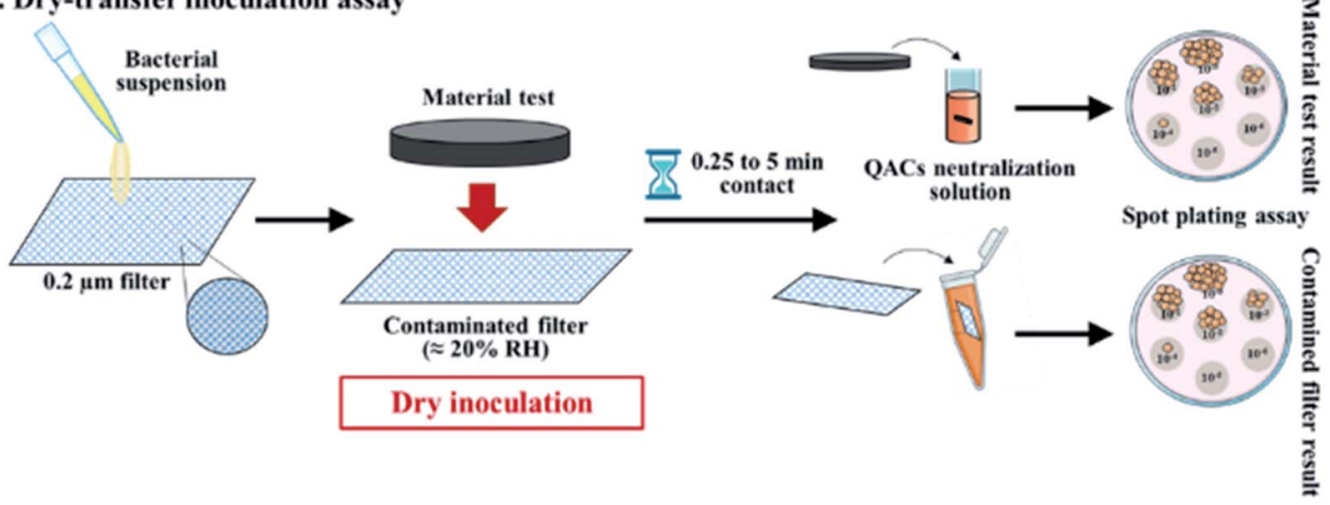

Fig. 1 Schematic representation of (A) the swab liquid-inoculation assay, (B) the humid-transfer inoculation assay and (C) the dry-transfer inoculation assay.

bacteria remaining in the contaminated gel and after transfer onto the materials.

2.2.8. Antibacterial activity of materials using a drytransfer inoculation assay. A dry-transfer inoculation assay was performed to evaluate the effectiveness of materials to prevent bacterial cross-contamination under low humidity conditions representative of the surface of the skin (Fig. 1C). Aliquots of $10 \mu \mathrm{L}$ from a bacterial suspension $\left(10^{8} \mathrm{CFU} \mathrm{mL}^{-1}\right)$ were deposited on $0.2 \mu \mathrm{m}$ sterile nylon filters (Nylon membrane disk diameter $13 \mathrm{~mm}$ - filter $0.22 \mu \mathrm{m}$, GVS North America, USA). The inoculated filters were dried for $7 \mathrm{~min}$ under the biological hood in order to obtain a $\mathrm{RH}$ of $16.8 \pm 2.6 \%$, representative of the RH found in Stratum Corneum of human skin epidermis. ${ }^{45}$ The RH of the filter was measured by the oven drying technique $\left(160{ }^{\circ} \mathrm{C}\right)$ as mentioned above. The different materials were deposited on the inoculated filters for $0.25,1,5,15$ and $60 \mathrm{~min}$. Then, the number of surviving bacteria on the contaminated filter and after transfer on the materials were quantified as described above.

2.2.9. Effectiveness of bactericidal materials after washing with cleaning products. The impact of serial washes on the antibacterial properties of the materials copper, Al, AA and AA$\mathrm{AgNO}_{3} \mathrm{QACs}$ was evaluated. The materials underwent series of 0 , 5 or 10 washes using different solutions, including cleaning products commonly used in hospitals: (a) sterile nanopure water, (b) ethanol (70\% v/v), (c) Virox ${ }^{\mathrm{TM}} 5$ containing $\simeq 7 \% \mathrm{v} / \mathrm{v}$ of hydrogen peroxide (utilization: diluted 1/16; v/v), (d) QACsbased impregnation solution (diluted $8 \mathrm{~mL}$ in $1 \mathrm{~L}$ ). When applicable, each wash was performed following the procedure called "disinfection of medical devices" recommended by the cleaning companies. The washes carried out with Virox ${ }^{\mathrm{TM}} 5$ (The Butcher Company, WI, USA) and the QACs solution were applied to the materials for 5 and $10 \mathrm{~min}$, respectively. The product was dried in air and a water wash was carried out to 
eliminate the residues of cleaning products on the materials. The washes with sterile nanopure water and ethanol were performed directly, without rinsing. Following these series of washes, the antibacterial efficiency of the materials was evaluated following the swab test methodology, using $S$. aureus and a constant inoculum-material contact time of $1 \mathrm{~h}$. In parallel, copper, $\mathrm{Al}, \mathrm{AA}$ and $\mathrm{AA}-\mathrm{AgNO}_{3}-\mathrm{QACs}$ without wash with cleaning solution were used as controls.

2.2.10. Efficiency of A3S materials following immersions in water. $\mathrm{AA}-\mathrm{AgNO}_{3}-\mathrm{QACs}$ underwent series of 1 to 10 successive $12 \mathrm{~h}$ immersions in $1 \mathrm{~mL}$ of sterile nanopure water. Between each successive immersion, the used deionized water was replaced with $1 \mathrm{~mL}$ of fresh sterile nanopure water. Following these series of immersions, the antibacterial efficiency of the $\mathrm{AA}-\mathrm{AgNO}_{3}$-QACs was evaluated with the swab liquidinoculation methodology, using $S$. aureus and a constant inoculum-material contact time of $1 \mathrm{~h}$. In parallel, the same experiment was repeated using AA control samples and AA$\mathrm{AgNO}_{3}-\mathrm{QACs}$ treated samples which had not been immersed in sterile nanopure water.

2.2.11. Statistical analyses. Analysis of variance (ANOVA) and subsequent statistical tests (Tukey-Kramer studentized range post-hoc tests) were performed using Excel (Excel 2013®) and GraphPad (GraphPad Software 2020 Inc., Prism 8, San Diego, CA, USA). Only difference with a $p<0.05$ were considered significant. In the current paper, the number of independent experiments is defined as " $n$ " and the total number of technical replicates per condition is defined as " $N$ ".

\section{Results and discussion}

\subsection{Characterization of anodized aluminum materials}

All the anodized aluminum-based materials (with or without impregnation) used in this study were prepared and provided by the company A3S (Fig S1 $\dagger$ ).

\subsubsection{Surface characterization}

Hydrophobicity by contact angle measurement. Since wettability of surfaces can influence the first stage of pathogen adhesion on materials, ${ }^{\mathbf{4 6 , 4 7}}$ static contact angle measurements were carried out using a goniometer to assess the surface wettability of $\mathrm{Al}, \mathrm{AA}, \mathrm{AA}-\mathrm{AgNO}_{3}, \mathrm{AA}-\mathrm{QACs}, \mathrm{AA}-\mathrm{AgNO}_{3}-\mathrm{QACs}$ and copper. As shown in Table 1, the reference materials copper and $\mathrm{Al}$ exhibited a slight hydrophobicity of their surface (around $78-85^{\circ}$ ), in accordance with previously published data. ${ }^{48-51}$

In contrast, the anodization process on Al significantly decreased the contact angle (around $49^{\circ}$ ), the AA being more hydrophilic than $\mathrm{Al}(p<0.001)$. These results are in contradiction with the hydrophobic/superhydrophobic properties normally induced by the hard anodization process of aluminum materials. ${ }^{52-54}$

However, this difference was probably induced during the final stage of manufacturing AA materials by the company A3S, which consists of pore sealing process by hydration of alumina molecules on the surfaces leading to dilatation and gradual closure of the alumina oxide layer. ${ }^{55}$ Furthermore, the impregnation step with QACs modified the wettability of AA. Indeed, unlike AA$\mathrm{AgNO}_{3}$, which showed similar contact angle in comparison with non-impregnated AA, AA-QACs partially restored the hydrophobicity lost following anodization $(p<0.001)$. QACs cations are composed of a positively charged nitrogen atom with four long non-polar carbon chains, which, used as a coating, can influence the surface hydrophobicity of the material. ${ }^{56-59}$ Thus, the type of solution used during the material impregnation step influences their surface wettability property. Generally, super-hydrophobic materials $\left(\theta>150^{\circ}\right)$ are recommended for antibacterial applications, since they inhibit cellular adhesion. ${ }^{60}$

Observation of the anodization layer by scanning electron microscopy. Cross sections were carried out to characterize by scanning electron microscopy the anodization layer of AA with or without $\mathrm{AgNO}_{3}-\mathrm{QACs}$ impregnation (Fig. 2). As expected, untreated aluminum $\mathrm{Al}$ did not show any layer at its surface. However, hard anodized AA and AA-AgNO ${ }_{3}-\mathrm{QACs}$ possessed over all of their surface a homogeneous layer of anodization with a thickness of about $50 \mu \mathrm{m}$. This layer was composed of organized arrays of pores with an overall diameter of 65-70 $\mathrm{nm}$ (the narrowing of the diameter of pores on anodized aluminum materials, due to the clogging stage, is not considered in these analyses) (Fig. 2). These results agree well with those of other studies showing the formation of an anodized layer thickness ranging from 25 to $100 \mu \mathrm{m}$ with pore diameters between 58 and $134 \mathrm{~nm}$ depending on the operating parameters (acid solution, temperature, current density). ${ }^{53,61,62}$

Hard anodization, consisting in electrolysis in a sulfuric acid solution $\left(\mathrm{H}_{2} \mathrm{SO}_{4}\right.$ : $\left.1-15 \% \mathrm{w} / \mathrm{v}\right)$, is performed at a low temperature

Table 1 Surface wettability of the materials using contact angle measurement by goniometer

Significant effect ${ }^{b}$

compared to

\begin{tabular}{|c|c|c|c|}
\hline Material & Contact angle measurement in static condition ${ }^{a}\left({ }^{\circ}\right)$ & $\mathrm{Al}$ & AA \\
\hline Copper & $78.05 \pm 3.77$ & - & $* *$ \\
\hline $\mathrm{Al}$ & $85.53 \pm 2.83$ & - & $* *$ \\
\hline $\mathrm{AA}$ & $48.99 \pm 6.76$ & $* *$ & - \\
\hline $\mathrm{AA}-\mathrm{AgNO}_{3}$ & $45.96 \pm 5.53$ & $* *$ & $\longrightarrow$ \\
\hline AA-QACs & $67.25 \pm 4.00$ & $*$ & $*$ \\
\hline $\mathrm{AA}-\mathrm{AgNO}_{3}-\mathrm{QACs}$ & $69.37 \pm 4.49$ & $*$ & $*$ \\
\hline
\end{tabular}

${ }^{a}$ Results are means $\pm \operatorname{SD}(n=2 ; N=24) .{ }^{b}$ Significant effect $* p<0.01$ and ${ }^{* *} p<0.001$. 


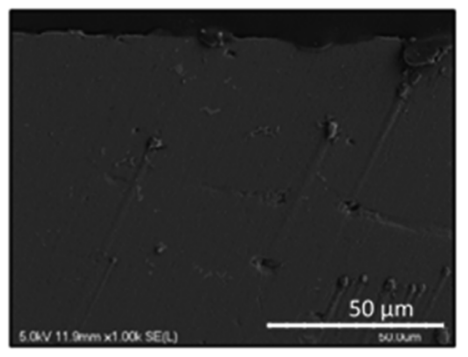

Al

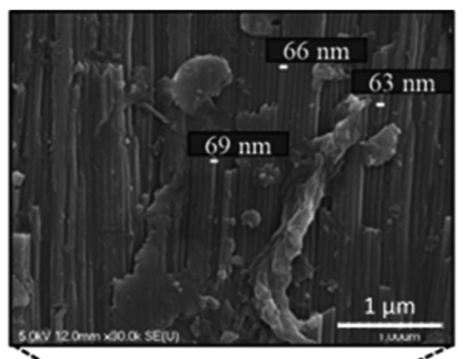

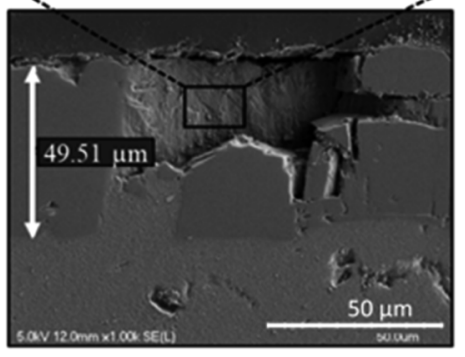

AA

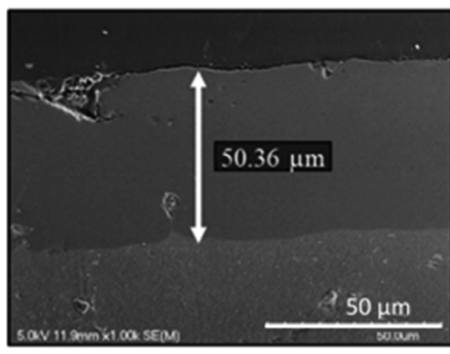

$\mathrm{AA}-\mathrm{AgNO}_{3}$-QACs

Fig. 2 Characterization of the anodized layer of reference materials using cross sectional observation by scanning electron microscopy. Results are representative of two independent experiments and four replicates.

(between -5 and $5{ }^{\circ} \mathrm{C}$ ) with a high current density $\left(20 \mathrm{~mA} \mathrm{~cm}^{-2}\right)$ and an anodization time varying between 60 to 90 min. ${ }^{63,64}$ Therefore, bacillus-shaped $(\simeq 1.0 \mu \mathrm{m}$ wide by $3.0 \mu \mathrm{m}$ long) and coccus-shaped $(\simeq 1.0 \mu$ m diameter) bacteria would be in contact with $\simeq 780$ and 200 pores, respectively, when deposited on these surfaces.

3.1.2. Release kinetics of antibacterial agents impregnated on anodized aluminum materials

Quaternary ammonium compounds (QACs) release kinetics. The release kinetics of the QACs were carried out on $\mathrm{AA}, \mathrm{AA}-\mathrm{AgNO}_{3}$,

\section{XAA XAA-AgNO 3 XAA-QACs $\quad$ XAA-AgNO ${ }_{3}$-QACs}

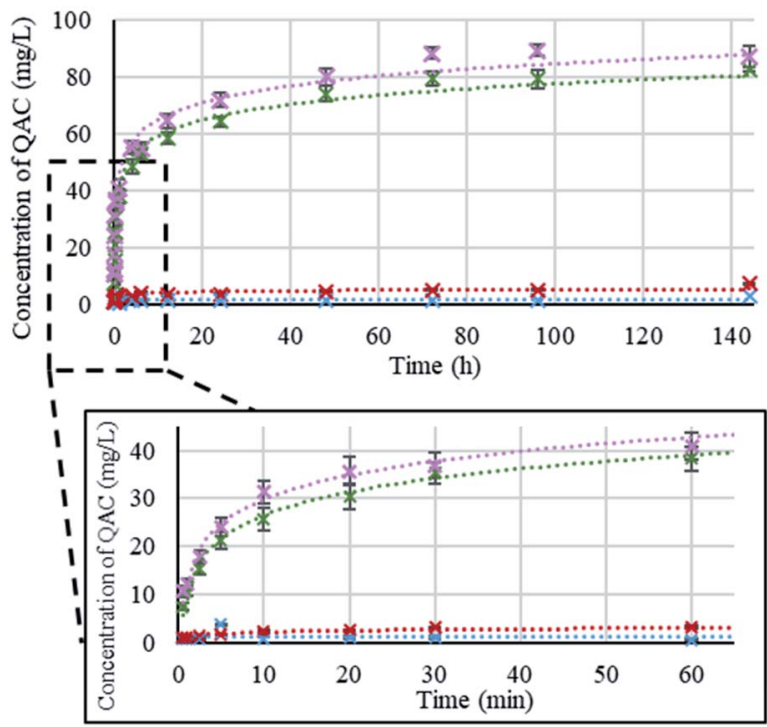

Fig. 3 Amount of QACs released $\left(\mathrm{mg} \mathrm{L}^{-1}\right)$ from anodized aluminum materials after immersion in nanopure water for different periods of time. Results are means $\pm \mathrm{SD}(n=4 ; N=12)$.
$\mathrm{AA}-\mathrm{QACs}$ and $\mathrm{AA}-\mathrm{AgNO}_{3}-\mathrm{QACs}$ (Fig. 3). The quantification of QACs release was calculated from a standard curve (Fig. S2 $\dagger$ ). As expected, no release of QACs was detected from both AA (negative control) and $\mathrm{AA}-\mathrm{AgNO}_{3}$. The release kinetics for $\mathrm{AA}-$ QACs and $\mathrm{AA}-\mathrm{AgNO}_{3}-\mathrm{QACs}$ were very similar and showed an extremely fast QACs release, from the first minutes of immersion in water, followed by a slower release up to $72 \mathrm{~h}$ of immersion (around 20 and $40 \mathrm{mg} \mathrm{L}^{-1}$ of QACs released after $5 \mathrm{~min}$ and $1 \mathrm{~h}$ of immersion, respectively). These two distinct phases are characteristic of release patterns from nanoporous anodized aluminum structures in non-agitated systems. ${ }^{\mathbf{6 5 , 6 6}}$

Therefore, the use of these materials in liquid environments (immersed) is not recommended.

Silver ion $\left.\mathrm{Ag}^{+}\right)$release kinetics. Tests using ICP-OES, allowing an ion detection level of $23 \mathrm{ppb}$, were carried out to assess the release of $\mathrm{Ag}^{+}$from $\mathrm{AA}-\mathrm{AgNO}_{3}-\mathrm{QACs}$. No $\mathrm{Ag}^{+}$could be detected following an immersion for up to $1 \mathrm{~h}$ and $24 \mathrm{~h}$, which is consistent with the study carried out by Valiei et al. ${ }^{36}$ Hence, the impact of $\mathrm{Ag}^{+}$on the antibacterial activity of the impregnated surfaces is expected to be minimal compared to that of QACs, as suggested also by our Minimal Inhibitory Concentration (MIC) and Minimal Bactericidal Concentration (MBC) assays.

\subsection{Minimal Inhibitory Concentration (MIC) and Minimal Bactericidal Concentration (MBC) assay}

Before assessing the antibacterial efficiency of impregnated materials, it was essential to first characterize the activity of antibacterial agents selected for impregnation of the surface materials. The MIC and MBC of (i) $\mathrm{AgNO}_{3}$ (1\% w/v), (ii) QACsbased $(10.9 \% \mathrm{w} / \mathrm{v})$ solution and (iii) a combination of both $\mathrm{AgNO}_{3}(1 \% \mathrm{w} / \mathrm{v})$ and QACs-based $(10.9 \% \mathrm{w} / \mathrm{v})$ solutions were determined on the pathogenic bacteria $S$. aureus, C. difficile, vancomycin-resistant E. faecium and E. faecalis, E. coli, 
Table $2 \mathrm{MIC}$ and $\mathrm{MBC}$ of impregnation solutions $\left(\mathrm{AgNO}_{3}, \mathrm{QACs}\right.$ and $\left.\mathrm{AgNO}_{3}+\mathrm{QACs}\right)$ on different Gram-positive and Gram-negative bacteria stains $^{a}$

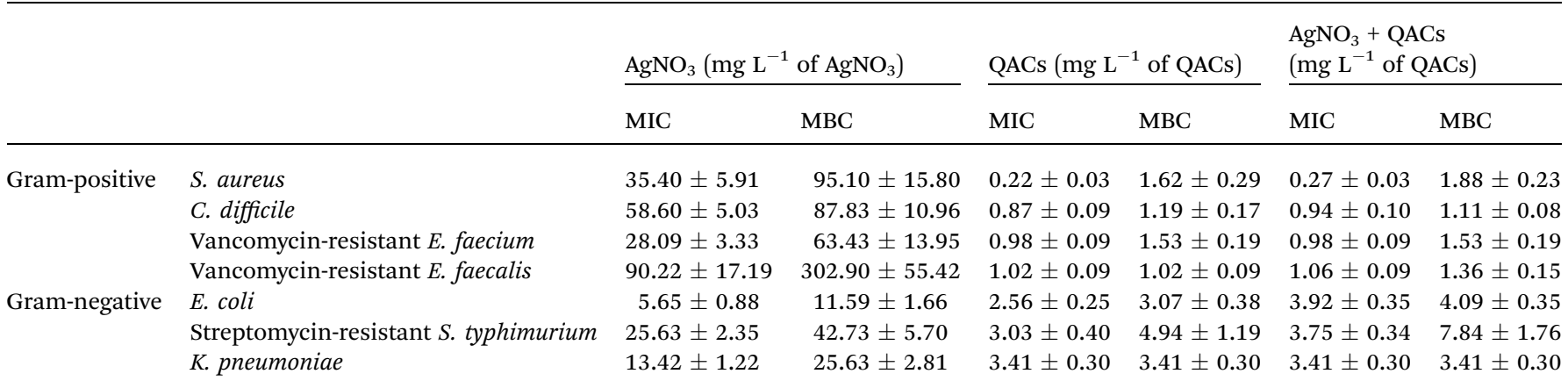

${ }^{a}$ Results are means $\pm \operatorname{SEM}(n=4 ; N=16)$.

streptomycin-resistant $S$. typhimurium and $K$. pneumoniae after 18-24 h incubation (Table 2).

The mechanism of action of $\mathrm{AgNO}_{3}$ is induced by the release of $\mathrm{Ag}^{+}$in solution. These ions bind to the thiol groups of proteins in cell membranes, enzymes and DNA, causing their denaturation and affecting their functions. ${ }^{67,68}$ For all the bacteria, MIC and MBC obtained with the $\mathrm{AgNO}_{3}$ solution varied between 5.65 and $90.22 \mathrm{mg} \mathrm{L}^{-1}$ and between 11.59 and $302.90 \mathrm{mg} \mathrm{L}^{-1}$, respectively (Table 2). These values are in accordance with the MIC range identified in the literature for $S$. aureus, E. coli and vancomycin-resistant enterococci. ${ }^{6-72}$ MIC and MBC values were also significantly higher for Gram-positive bacteria (MIC between 28.09 and $90.22 \mathrm{mg} \mathrm{L}^{-1}$ and $\mathrm{MBC}$ between 63.43 and $302.90 \mathrm{mg} \mathrm{L}^{-1}$ ) than for Gram-negative bacteria (MIC between 5.65 and $25.63 \mathrm{mg} \mathrm{L}^{-1}$ and $\mathrm{MBC}$ between 11.59 and $\left.42.73 \mathrm{mg} \mathrm{L}^{-1}\right)(p<0.0001$; Table 2). On the other hand, the MIC and MBC values for bacteria resistant to vancomycin (E. faecium and E. faecalis) or streptomycin ( $S$. typhimurium), were similar to other bacteria of their Grampositive and Gram-negative groups, respectively (Table 2).

QACs mainly damage the cytoplasmic membrane of bacteria by disrupting the lipid bilayers through the alkyl chains of QACs molecules. ${ }^{73}$ This mode of action is attributed to various factors such as molecular weight, molecular charge density or the length of the QACs $N$-alkyl chains. ${ }^{74-82}$ The evaluation of the QACs solutions showed MIC ranging from 0.22 to $3.41 \mathrm{mg} \mathrm{L}^{-1}$ and $\mathrm{MBC}$ ranging from 1.02 to $4.94 \mathrm{mg} \mathrm{L}^{-1}$, coinciding perfectly with values found in the literature for chlorinated QACs $(0.25$ to $\left.5.0 \mathrm{mg} \mathrm{L}{ }^{-1}\right) .{ }^{83-86}$ A significant difference between Gram-positive and Gram-negative bacteria was observed for the QACs solution and was inversed with what was observed for the $\mathrm{AgNO}_{3}$ solution. Indeed, MIC and MBC values were significantly lower for Gram-positive bacteria (MIC between 0.22 and $1.02 \mathrm{mg} \mathrm{L}^{-1}$ and MBC between 1.02 and $1.62 \mathrm{mg} \mathrm{L}^{-1}$ ) than for Gram-negative bacteria (MIC between 2.56 and $3.41 \mathrm{mg} \mathrm{L}^{-1}$ and $\mathrm{MBC}$ between 3.07 to $\left.4.94 \mathrm{mg} \mathrm{L}^{-1}\right)(p<0.0001$; Table 2).

Although QACs are broad-spectrum antibacterial agents against Gram-positive and Gram-negative bacteria, the cell wall of Gram-positive cells is composed of a single plasma membrane, generally making them more sensitive to QACs than Gram-negative bacteria that possess two lipid bilayers. ${ }^{87,88}$
In addition, for all the tested bacteria, MIC and MBC obtained with the $\mathrm{AgNO}_{3}$ solution were significantly higher (100 to 1500 times) than those obtained with the QACs solutions ( $p<$ 0.0001), demonstrating the strong antibacterial efficiency of QACs on Gram-positive and Gram-negative bacteria. This likely explains why MIC and MBC values with the $\mathrm{AgNO}_{3}+$ QACs combination were quite similar to those obtained with the QACs alone (Table 2).

All the results described above were performed on vegetative bacteria, i.e., metabolically active bacteria. Since bacterial spores represent important vehicles for dissemination of certain bacterial pathogens, the sporicidal potential of the impregnating solutions was assessed on $C$. difficile spores $(\simeq 1.6$ $\times 10^{5}$ spores per $\mathrm{mL}$ ), following contact times of 1,4 and $24 \mathrm{~h}$. The sporicidal disinfectant Virox ${ }^{\mathrm{TM}} 5$ was used as a comparison control (Fig. S3†). The results showed that none of the QACscontaining solutions (QACs alone or $\mathrm{AgNO}_{3}+$ QACs) induced a significant decrease in the number of $C$. difficile spores, as opposed to the sporicidal controls $\left(1 / 16(\mathrm{v} / \mathrm{v})\right.$ : Virox ${ }^{\mathrm{TM}} 5 /$ water $)$ for which no viable spores were detected (Fig. S3†). These results are in agreement with the literature showing that QACs are generally non-sporicidal. ${ }^{89}$

However, in this study, all the vegetative bacteria showed great sensitivity to the QACs-containing solutions, thus justifying the interest of their use for manufacturing antibacterial surfaces.

\subsection{Assessing the antibacterial properties of materials on different pathogenic bacteria}

The antibacterial activity of materials was evaluated against both Gram-positive ( $S$. aureus, $C$. difficile, vancomycin-resistant E. faecium) and Gram-negative pathogens (streptomycinresistant $S$. typhimurium and $K$. pneumoniae possessing a capsule) following contact times from 0.25 to $60 \mathrm{~min}$. In addition, we compared three different inoculation methods (Fig. 1): (i) a swab liquid-inoculation assay (Fig. 4), (ii) a humidtransfer inoculation assay from a contaminated gel (Fig. 5) and (iii) a dry-transfer inoculation assay from a contaminated filter (Fig. 6). These different methodologies were chosen to allow comparison of the antibacterial activity of materials under different humidity conditions, to mimic wet (fomites, aerosols) 
and dry (contaminated hands of patients, medical equipment or other inert objects) environments associated with transmission of bacterial pathogens. ${ }^{90-92}$ Fig. 4-6 show the results with copper (antibacterial control), AA (negative control) and $\mathrm{AA}-\mathrm{QACs}$, while results obtained with $\mathrm{Al}, \mathrm{AA}-\mathrm{AgNO}_{3}$ (identical results to the $\mathrm{AA}$ control) and $\mathrm{AA}-\mathrm{AgNO}_{3}-\mathrm{QACs}$ (identical results to AA-QACs) are presented in ESI (Fig. S4-S6†).

3.3.1. Antibacterial activity of materials using swab liquidinoculation assay. The initial number of bacteria recovered from negative control AA was $\simeq 1.6 \times 10^{6} \mathrm{CFU}$ per surface, as determined after a 0 min contact time. This inoculum was sufficient to observe a 3-log decrease in bacterial viability (99.9\% antibacterial activity). ${ }^{43}$ Bacterial counts were stable on both $\mathrm{Al}$ and AA negative control materials with $\simeq 1.6 \times 10^{6} \mathrm{CFU}$ per surface within $60 \mathrm{~min}$ for all tested bacteria (Fig. 4 and $\mathrm{S} 4 \dagger$ ), showing that the anodization process alone did not confer antibacterial property on Al. Compared to AA, copper showed a significant decrease in bacterial counts (99.9\%, corresponding to a 3-log CFU per surface decrease) after $15 \mathrm{~min}$ with $S$. aureus and $C$. difficile $\left(1.5 \times 10^{3}\right.$ and $1.4 \times 10^{2} \mathrm{CFU}$ per surface, respectively), and after $60 \mathrm{~min}$ with $S$. typhimurium $\left(3.1 \times 10^{2}\right.$ CFU per surface) (Fig. 4). These values are in agreement with the well-known antibacterial properties of copper (C70600 alloy), inducing 99.9\% antibacterial activity after 15 and $30 \mathrm{~min}$ of contact with $E$. coli and $S$. aureus, respectively. ${ }^{93,94}$ Another study showed that against $C$. difficile, copper showed the same antibacterial activity (99.9\%) after $240 \mathrm{~min}^{95}$

$\mathrm{AA}-\mathrm{AgNO}_{3}$ had no significant effect on bacterial viability for all contact times, demonstrating that impregnation with an
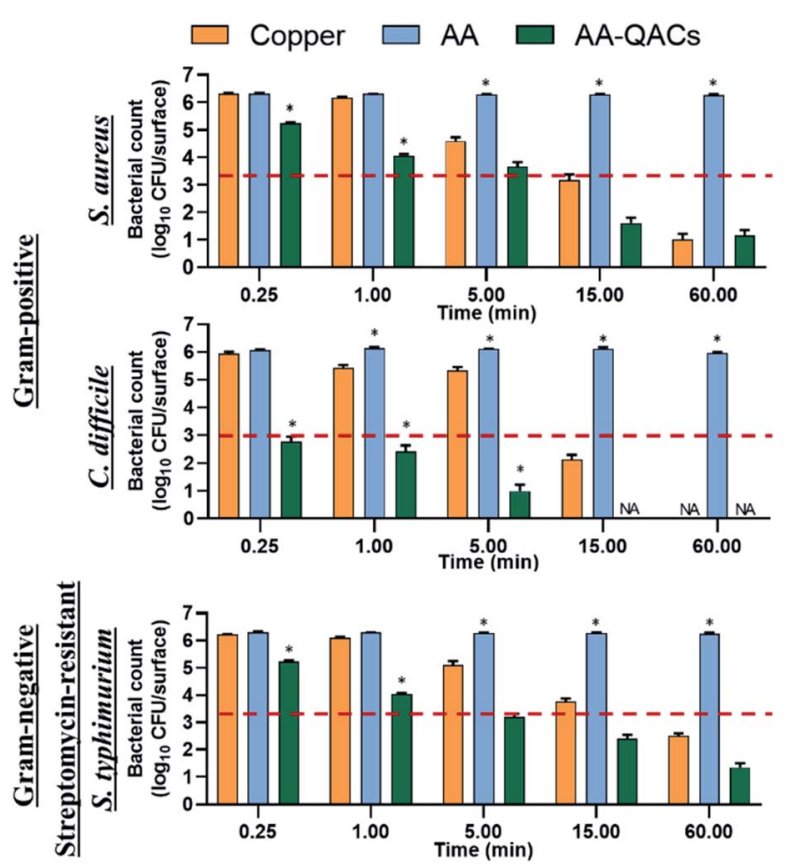

Fig. 4 Swab liquid-inoculation assay evaluating the antibacterial activity of different materials. Results are means $\pm \operatorname{SEM}(n=2 ; N=8)$. The reference of $99.9 \%$ antibacterial activity is indicated by the dotted red line. Statistical effect compared to copper: ${ }^{*} p<0.001$. NA: no bacteria counted.
$\mathrm{AgNO}_{3}(1 \% \mathrm{w} / \mathrm{v})$ solution did not induce antibacterial activity on AA within 60 min (Fig. S4 $\dagger$ ). This was expected based on our MIC and MBC assays (Table 2), as well as the release kinetics assays (Fig. 3). In contrast, the AA-QACs caused a greater bacterial decrease than AA and copper after 0.25 and 1 min of contact, for all the bacteria ( $p<0.001$ : Fig. 4$)$. For example, AAQACs showed 99.9\% antibacterial activity after $0.25 \mathrm{~min}$ for $C$. difficile ( $p<0.001$ : $6.0 \times 10^{3} \mathrm{CFU}$ per surface), $5 \mathrm{~min}$ for $S$. typhimurium ( $p<0.001: 1.5 \times 10^{3} \mathrm{CFU}$ per surface) and $15 \mathrm{~min}$ of contact with $S$. aureus ( $p<0.001: 4.1 \times 10^{1} \mathrm{CFU}$ per surface). The antibacterial effect of AA-QACs was even more pronounced after longer contact times, decreasing the quantity of surviving bacteria to $<2.0 \times 10^{1} \mathrm{CFU}$ per surface after $5 \mathrm{~min}$ for $C$. difficile $\left(1.04 \times 10^{1} \mathrm{CFU}\right.$ per surface) and $60 \mathrm{~min}$ for $S$. aureus and $S$. typhimurium $\left(1.4 \times 10^{1}\right.$ and $1.9 \times 10^{1} \mathrm{CFU}$ per surface, respectively) (Fig. 4). Finally, similar results to AA-QACs were obtained with $\mathrm{AA}-\mathrm{AgNO}_{3}-\mathrm{QACs}$ (Fig. $\mathrm{S} 4 \dagger$ ).

Although we did not observe sporicidal activity in MIC and MBC assays with the various impregnation solutions (Fig. S3 $\dagger$ ), we also tested the sporicidal activity of the different materials on $C$. difficile spores after 1 and 24 h of contact. As expected, no sporicidal effect could be observed when compared to the AA negative control (Fig. $\mathrm{S} 4 \dagger$ ).

In summary, under liquid conditions using the swab test, anodized aluminum materials impregnated with QACs showed a faster and stronger antibacterial activity against both Grampositive and Gram-negative bacteria compared to copper, whose alloy is approved as an antibacterial reference by EPA. ${ }^{39}$ In addition, the impregnation with $\mathrm{AgNO}_{3}$, alone or in combination with QACs, did not improve the overall activity of materials (Fig. S4 $\dagger$ ). Therefore, consistent with the MIC and $\mathrm{MBC}$ results, the effect of $\mathrm{AgNO}_{3}$ compared to QACs appeared to be negligible in this study.

3.3.2. Antibacterial activity of materials using a humidtransfer inoculation assay. We next wanted to assess the antibacterial properties of the different materials using a humidtransfer protocol, to mimic a wet contamination (fecal spills, contaminated aerosols, or food). To do this, we developed a gel contamination assay, which recreates conditions of high humidity, but without excessive liquid like with the swab method. Contact kinetics of $0.25,1,5,15$ and 60 min were done with $S$. aureus, C. difficile, vancomycin-resistant E. faecium, streptomycin-resistant $S$. typhimurium and $K$. pneumoniae (Fig. 5). The number of bacteria at time zero on contaminated gels was $\simeq 6.0 \times 10^{5} \mathrm{CFU} \mathrm{\textrm {cm } ^ { - 2 }}$, allowing a sufficient bacterial inoculum deposit on the materials to assess their antibacterial properties $\left(6.0 \times 10^{4}\right.$ and $4.0 \times 10^{5} \mathrm{CFU}$ per surface depending on the type of bacteria). ${ }^{43}$ The number of bacteria was stable over time on both $\mathrm{AA}$ and $\mathrm{Al}$ negative controls and their contaminated gels (Fig. 5 and $\mathrm{S} 5 \dagger$ ).

The copper induced a significant decrease of $99 \%$ in bacterial counts (2-log $\mathrm{CFU} \mathrm{cm}^{-2}$ decrease) on contaminated gels compared to AA after 60 min of contact with $S$. aureus, C. difficile, E. faecium and $S$. typhimurium ( $p<0.001$, Fig. 5A). In contrast, copper had little antibacterial activity on gels contaminated with $K$. pneumoniae (not significant). The low efficiency of copper on $K$. pneumoniae may be explained by the 

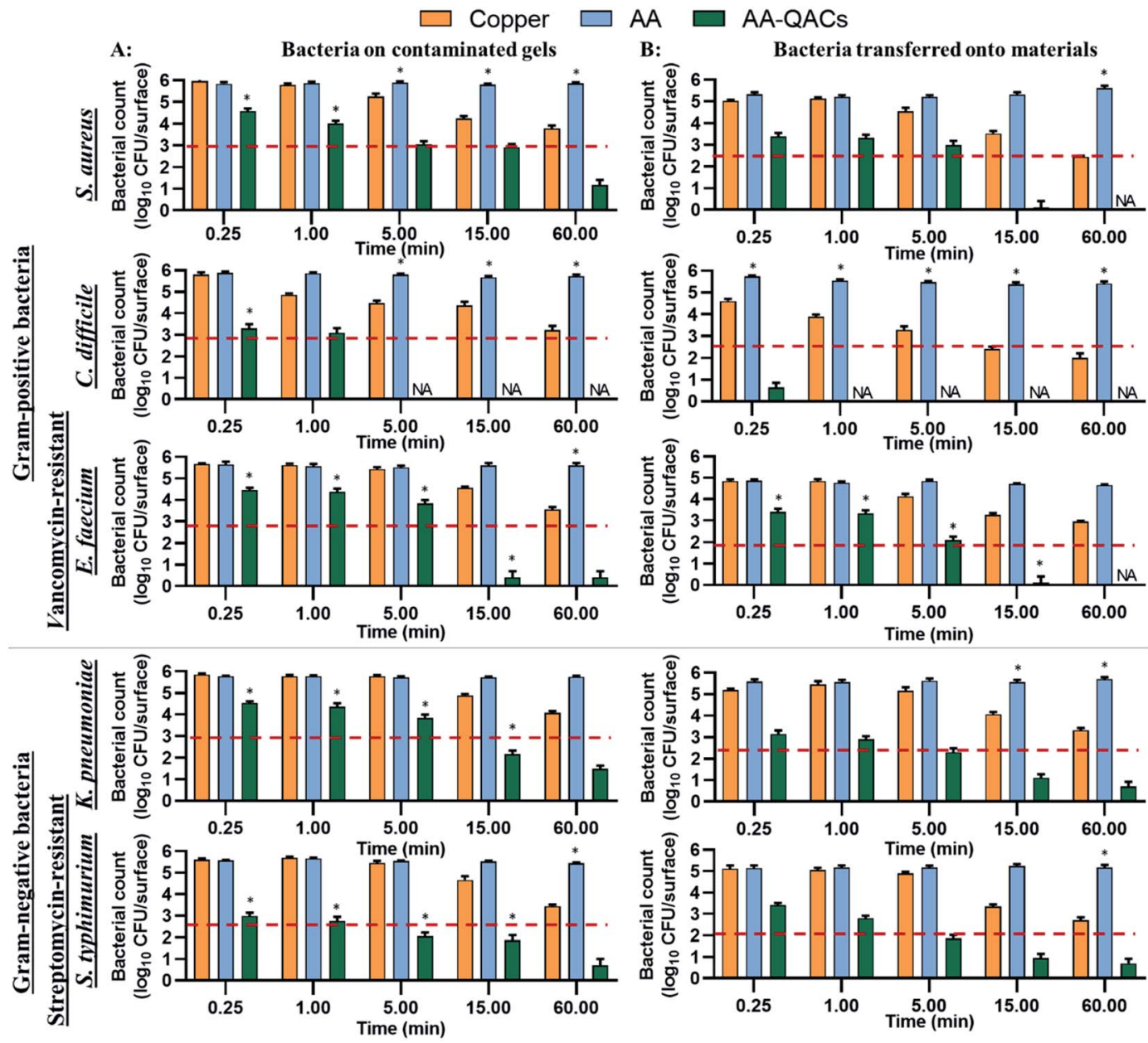

Fig. 5 Humid-transfer inoculation assay from contaminated gel evaluating the antibacterial activity of materials. The graph shows total counts of bacteria that survived (A) on the contaminated gel or (B) after transfer from the gel to the different materials. The reference of $99.9 \%$ antibacterial activity is indicated by the dotted red line. Results are means \pm SEM $(n=2 ; N=8)$. Statistical significance when compared to copper: ${ }^{*} p<0.001$. NA: no bacteria counted.

fact that this bacterium produces a thick polysaccharide capsule which provides protection against antibacterial agents, in addition to contributing to its virulence..$^{96-98}$ However, when assessing bacterial survival after transfer from the gel to the surface of the different materials, copper induced a significant decrease of $99.9 \%$ in S. aureus and C. difficile counts $(p<0.001)$ and of $99 \%$ in counts of $K$. pneumoniae, S. typhimurium ( $p<$ $0.001)$ and $E$. faecium $(p<0.01)$ after a contact time of $60 \mathrm{~min}$ (Fig. 5B). The release of copper ions is considered to be the key mechanism of antibacterial activity of these materials. ${ }^{99,100}$ In the humid-transfer inoculation assay, the reduced water content limits the release of copper ion, which might explain why copper presented a lower activity with the gel inoculation protocol than with the swab or international standards methodology. ${ }^{39,43}$

Furthermore, while $\mathrm{AA}$ and $\mathrm{AA}-\mathrm{AgNO}_{3}$ gave results similar to Al (Fig. S5 $\dagger$ ), AA-QACs had a greater antibacterial activity on contaminated gels after $0.25 \mathrm{~min}$ of contact for all bacteria, compared to the copper control ( $p<0.001$ : Fig. $5 \mathrm{~A}$ ). For example, the AA-QACs showed $99.9 \%$ antibacterial activity on contaminated gels after $5 \mathrm{~min}$ for $C$. difficile and S. typhimurium $(p<$
0.001: 0 and $1.1 \times 10^{2} \mathrm{CFU}$ per surface, respectively), and $15 \mathrm{~min}$ for $S$. aureus, E. faecium and K. pneumoniae ( $p<0.001$ : 8.2 $\times 10^{2}, 2.5 \times 10^{0}$ and $1.5 \times 10^{2} \mathrm{CFU}$ per surface, respectively). The antibacterial activity of AA-QACs was greater and faster following transfer of bacteria onto materials $\left(<1.0 \times 10^{2} \mathrm{CFU}\right.$ per surface; Fig. 5B), resulting in $99.995 \%$ of bacteria killed after 0.25 min of contact with $C$. difficile $\left(p<0.001: 4.2 \times 10^{1} \mathrm{CFU}\right.$ per surface) and after $15 \mathrm{~min}$ of contact with $S$. aureus, E. faecium, $K$. pneumoniae and S. typhimurium $\left(p<0.001: 1.2 \times 10^{\circ}, 1.3 \times 10^{\circ}\right.$, $1.3 \times 10^{1}$ and $8.8 \times 10^{1} \mathrm{CFU}$ per surface, respectively).

Finally, $\mathrm{AA}-\mathrm{AgNO}_{3}-\mathrm{QACs}$ showed a great efficiency, equivalent to AA-QACs, confirming that the addition of $\mathrm{AgNO}_{3}$ did not improve the overall activity of the materials (Fig. S5†).

3.3.3. Antibacterial activity of materials using a drytransfer inoculation assay. The dry contamination of hightouch surfaces, for example through contaminated hands, tissues, medical devices or other objects, actively participates in the transmission of pathogenic bacteria in both hospital and community environments. ${ }^{90-92}$ Therefore, tests mimicking bacterial dry-transfer were carried out to assess the killing efficiency of antibacterial materials in a similar context. To this 
end, we developed a filter contamination assay that recreates low humidity conditions $(<20 \% \mathrm{RH})$. Contact times of $0.25,1$ and $5 \mathrm{~min}$ were used in assays with $S$. aureus, C. difficile, vancomycin-resistant $E$. faecium, streptomycin-resistant $S$. typhimurium and $K$. pneumoniae (Fig. 6). The number of bacteria at time zero on the contaminated filters was $\simeq 1.0 \times 10^{6} \mathrm{CFU}$ $\mathrm{cm}^{-2}$. The initial number of bacteria deposited on each material varied between $6.9 \times 10^{4}$ and $7.8 \times 10^{5} \mathrm{CFU}$ per surface depending on the bacterial species tested. The initial quantity of inoculum on all contaminated filters, was stable over time (0.25, 1 and $5 \mathrm{~min}$ ) for all bacteria (Fig. 6A). The different materials tested had no impact on the viability of bacteria present on the filters and the number of bacteria transferred to both AA and Al negative controls remained stable over time for all bacteria species (Fig. 6B). The copper showed only an antibacterial activity of $99 \%$ (2-log CFU per surface decrease) after 1 and 5 min of contact with C. difficile $\left(p<0.001: 7.4 \times 10^{2} \mathrm{CFU}\right.$ per surface) and killed less than $90 \%(\leq 1-\log$ CFU per surface decrease) of $S$. aureus, E. faecium, $K$. pneumoniae and $S$. typhimurium (Fig. 6). These results differ from those obtained with the gel inoculation protocol, where copper had antibacterial activity greater than $99.9 \%(\geq 3 \log$ of CFU per surface decrease) after $60 \mathrm{~min}$ of contact (Fig. 5B). This difference can be explained by the fact that contact times $\leq 5 \mathrm{~min}$ in dry conditions would not allow the sufficient release of copper ions to induce bacterial death.9,100 This demonstrates the relevance of assessing different methodologies and contamination protocols mimicking real conditions to which materials will be exposed to (short contact time, low humidity, etc.). ${ }^{\mathbf{1 0 1 , 1 0 2}}$ Moreover, the number of bacteria transferred to $\mathrm{AA}-\mathrm{AgNO}_{3}$ was not affected over time for all bacteria (Fig. S6B $\dagger$ ). In contrast, AA-QACs induced a significant decrease of more than $99.5 \%$ bacteria after 1 min of contact with $S$. aureus, C. difficile, E. faecium, K. pneumoniae and S. typhimurium ( $p$ $<0.001$ : $1.2 \times 10^{3}, 2.9 \times 10^{2}, 2.6 \times 10^{2}, 1.3 \times 10^{3}$ and $2.5 \times 10^{3}$ CFU per surface, respectively) (Fig. 6). Similar results were obtained with $\mathrm{AA}-\mathrm{AgNO}_{3}-\mathrm{QACs}$ (Fig. S6B $\dagger$ ).

To summarize, by mimicking liquid and humid transmission routes (swab and humid-transfer assay), responsible for frequent

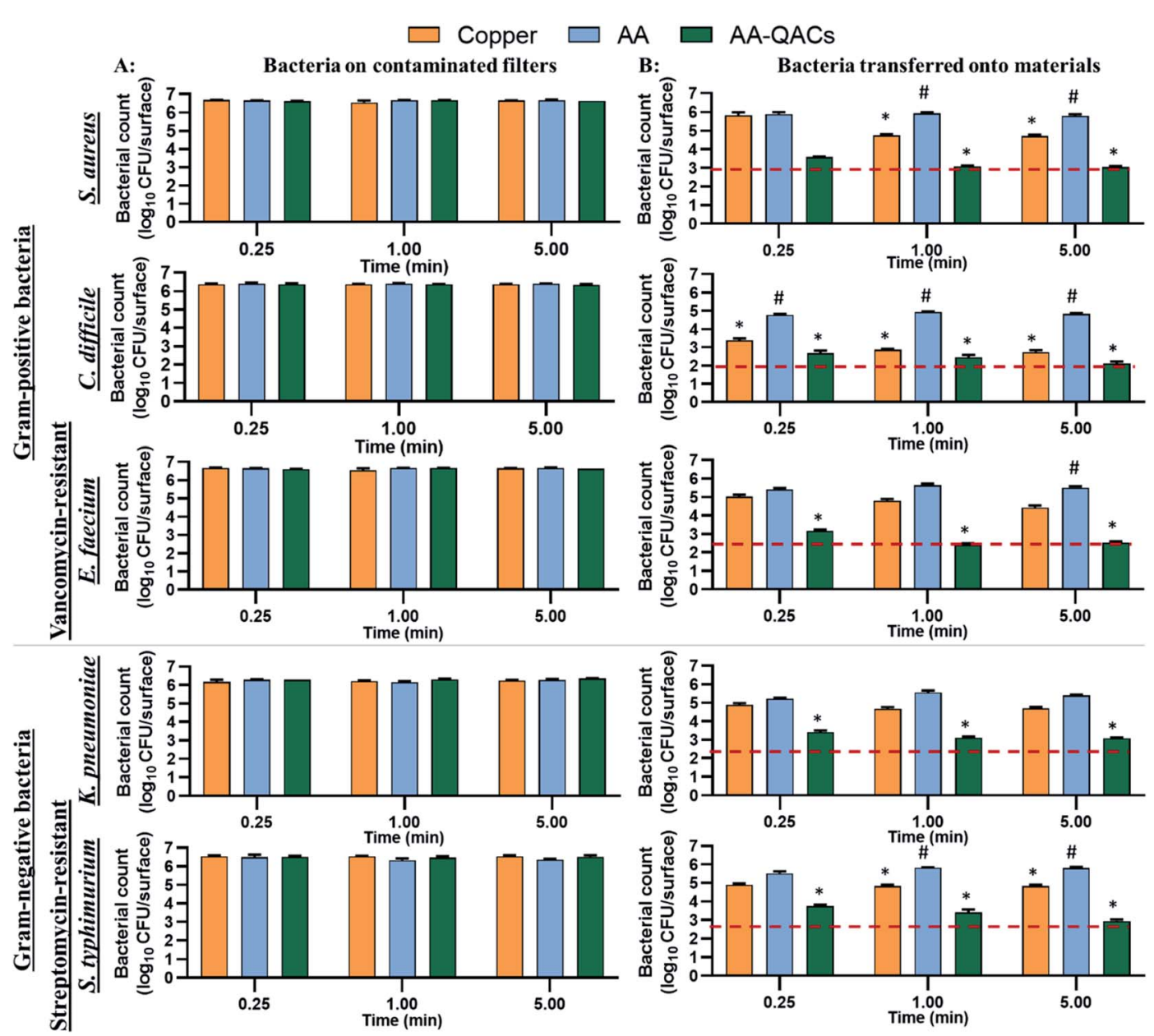

Fig. 6 Dry-transfer inoculation assay evaluating the antibacterial activity of materials after contact with a contaminated filter under low humidity conditions. Bacterial counts in $\log _{10}$ CFU per surface are indicated for (A) contaminated filters and (B) after transfer onto materials. Results are means \pm SEM $(n=2 ; N=8)$. The reference of $99.9 \%$ antibacterial activity is indicated by the dotted red line. Statistical effect compared to AA: * $p<$ 0.001 and to copper: $\# p<0.001$. 
hospital and community contaminations (fecal spills, aerosols, contaminated food), AA containing QACs showed a high and quick antibacterial efficiency (more than 99.95\% in less than $15 \mathrm{~min}$ ) on all pathogenic vegetative bacteria tested, thus exceeding the antibacterial activity required by standardization agencies ${ }^{\mathbf{4 3 , 1 0 3}}$ (Fig. 4 and 5). In addition, by mimicking contamination under dry conditions, these materials showed promising results even for short contact times (e.g., $1 \mathrm{~min}$ ) and were more efficient than the copper reference (Fig. 6). This high antibacterial performance in short contact times is a highly desired feature in the manufacturing of high-touch antibacterial surfaces since it is crucial to reduce pathogenic transmission linked to the contaminated inert environment. In fact, in public areas with high contact surfaces, such as in hospitals, the average elapsed time between two people touching the same surface is estimated at 5 min. ${ }^{\mathbf{1 0 1 , 1 0 2}}$ Following humid contact, the AA-QACs allowed the contaminated gels to be "partially sterilized" (99.9\% decrease in bacteria in less than 5 or 15 min of contact) (Fig. 5). However, AA-QACs had no impact on the viability of bacteria on the contaminated filters. Thus, the mode of action of AA-QACs appears to require the presence of humidity to induce sufficient release of the active agents from the material, consistent with the rapid release kinetic of QACs observed following material immersion (Fig. 3).

In our assays, the filter was the source of the contamination and it's relative humidity was $\simeq 20 \%$, which is similar to the superficial layers of Stratum Corneum in the human epithelium. ${ }^{45,104}$ Under these conditions, the release and transfer of QACs to the filter was negligeable. However, it was sufficient to allow effective and rapid antibacterial activity against bacteria transferred onto the materials. These results suggest that under RH conditions similar to those of the skin, AA-QACs may not have harmful impacts on the human skin or its microbiome (good bacteria colonizing the human skin playing an essential protective role ${ }^{\mathbf{1 0 5}}$ ), while enable self-disinfection of the contaminated surfaces. This would constitute a very important advantage since the disruption (dysbiosis) of this microbial balance can affect immune defenses, cause excessive inflammation of the skin tissue and lead to the development of pathologies such as acne or psoriasis. ${ }^{106,107}$ However, the impact of AA-QACs on the microbiome or human skin tissue must be determined in a future study.

\subsection{Effectiveness of antibacterial materials after washing with cleaning products}

The inert surfaces in public environments (door knobs, stair railings, support ramps, etc.) are regularly cleaned using specific sanitizing and disinfecting agents. ${ }^{108}$ To assess longevity of the AA-QACs materials, the effects of several cleaning products on the antibacterial properties of the materials were evaluated using $S$. aureus and a constant contact time of $1 \mathrm{~h}$ (Fig. 7). The tests assessed the impact of 0,5 and 10 consecutive washes with different cleaning solutions containing: (a) sterile water, (b) ethanol, (c) Virox ${ }^{\mathrm{TM}} 5$, and (d) a QACs-based commercial solution. No significant decrease in the number of surviving bacteria was observed on the $\mathrm{Al}$ and AA controls following 5 or 10 washes with sterile water or ethanol. However, a slight decrease in CFU per surface (1 log reduction), was observed on the $\mathrm{Al}$ and AA following 10 washes with Virox ${ }^{\mathrm{TM}} 5\left(5.8 \times 10^{5}\right.$ and $4.3 \times 10^{5}$ CFU per surface, respectively; $\left.p<0.0001\right)$ and 5 or 10 washes with the QACs solution $\left(1.7 \times 10^{5}\right.$ and $1.4 \times 10^{5} \mathrm{CFU}$ per surface for $\mathrm{Al}$ and $2.7 \times 10^{4}$ and $8.7 \times 10^{3} \mathrm{CFU}$ per surface for AA, respectively; $p<0.0001$ ) (Fig. 7). Antibacterial residues from the series of washes could explain this slight drop in bacterial counts on these negative control materials. Indeed, after their use, the elimination of QACs (cationic surfactant) requires the use of abundant rinsing. ${ }^{109}$ In addition, QACs such as ADBAC and DDAC have extremely low vapor pressures $\left(3.53 \times 10^{-12} \mathrm{~mm} \mathrm{Hg}(4.7 \times\right.$ $\left.10^{-10} \mathrm{~Pa}\right)$ and $2.33 \times 10^{-11} \mathrm{~mm} \mathrm{Hg}\left(3.1 \times 10^{-9} \mathrm{~Pa}\right)$, respectively). ${ }^{110,111}$ Therefore, the potential residues of these QACs do not volatilize spontaneously and persist on materials.

The antibacterial activity of copper remained relatively unaffected after washes with sterile water, ethanol or QACs solution. Similarly, the antibacterial activity of $\mathrm{AA}-\mathrm{AgNO}_{3}-\mathrm{QACs}$ was relatively unaffected by 5 or 10 washes with sterile water or ethanol. However, Virox ${ }^{\mathrm{TM}} 5$ washes resulted in a significant decrease in the antibacterial activity of copper $\left(3.6 \times 10^{3} \mathrm{CFU}\right.$ per surface, $p<0.01)$ and $\mathrm{AA}-\mathrm{AgNO}_{3}-\mathrm{QACs}\left(5.4 \times 10^{4} \mathrm{CFU}\right.$ per surface, $p<0.0001$ ) (Fig. 7). Hydrogen peroxide $\left(\mathrm{H}_{2} \mathrm{O}_{2}\right)$ is a strong oxidizing agent $\left(E_{\mathrm{o}}=1.763 \mathrm{~V}\right.$ at $\mathrm{pH} 0, E_{\mathrm{o}}=0.878 \mathrm{~V}$ at pH 14). ${ }^{112}$ Thus, it alters the copper by electrochemical dissolution, resulting in a maximum elimination rate of copper with $1 \% \mathrm{H}_{2} \mathrm{O}_{2}$ (Virox ${ }^{\mathrm{TM}} 5$ use concentration $\simeq 0.5 \% \mathrm{H}_{2} \mathrm{O}_{2}$ ). ${ }^{113}$ Moreover, clogging of anodized aluminum materials gives them

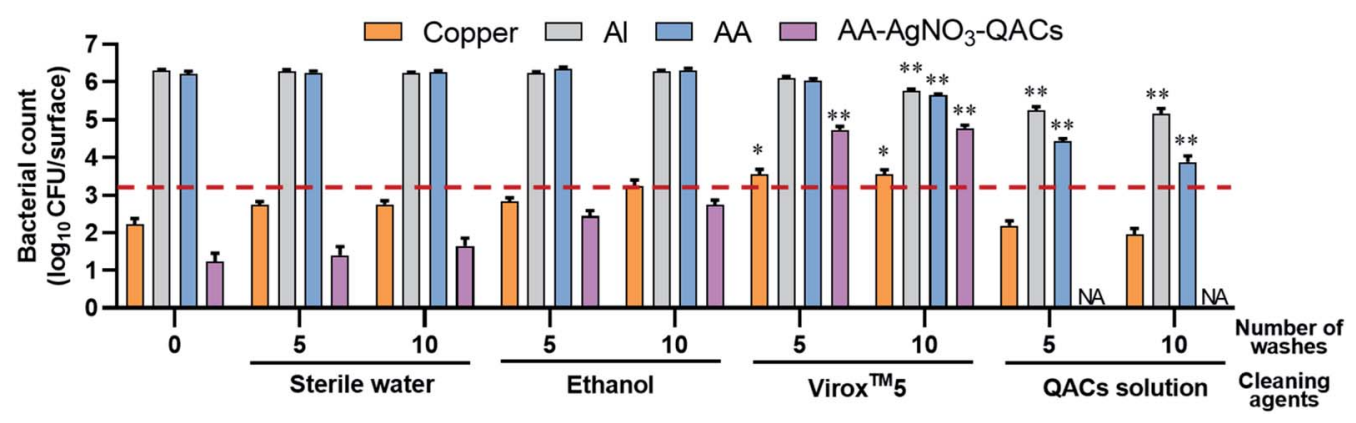

Fig. 7 Impact of 0, 5 or 10 consecutive washes with different cleaning solutions on the antibacterial properties of materials tested against $S$. aureus. The reference of $99.9 \%$ antibacterial activity is indicated by the dotted red line. Results are means $\pm \operatorname{SEM}(n=3 ; N=12)$. Statistical effect compared to the corresponding material without cleaning agent: ${ }^{*} p<0.01$ and ${ }^{*} p<0.0001$. NA: no bacteria counted. 
stability and protection against corrosion and abrasion..$^{55,114,115}$ However, in this study, the AA surface is covered by a nanoporous layer. Hence, $\mathrm{H}_{2} \mathrm{O}_{2}$ can penetrate into the anodized layer, affecting its integrity.

Of note, the washes carried out with the QACs solution improved the antibacterial properties of $\mathrm{AA}-\mathrm{AgNO}_{3}-\mathrm{QACs}$, with no viable counts detectable after 5 washes (Fig. 7). As in previous experiments, results similar to those obtained with $\mathrm{AA}-\mathrm{AgNO}_{3}-\mathrm{QACs}$ are expected from AA-QACs materials. In summary, the integrity of the AA impregnated with QACs, and their antibacterial properties must be maintained by using appropriate cleaning solutions (e.g., QACs solution), if repeated washing procedures are to be applied. The added advantage of such cleaning step is that it seems to improve the overall antibacterial efficiency of the materials.

\subsection{Effectiveness of antibacterial materials following immersions in water}

As demonstrated by our release kinetics assays, immersion of $\mathrm{AA}-\mathrm{QACs}$ (or $\mathrm{AA}-\mathrm{AgNO}_{3}-\mathrm{QACs}$ ) in water leads to a rapid release of QACs from the impregnated surfaces. To assess the impact of water immersion on the antibacterial activity of $\mathrm{AA}-\mathrm{AgNO}_{3}-$ QACs, and to determine the suitable applications for these materials, we tested the impact of a series of successive $12 \mathrm{~h}$ immersions in water. The swab liquid-inoculation assay was performed on $S$. aureus with a constant contact time of $1 \mathrm{~h}$ (Fig. 8). Without immersion, the $\mathrm{AA}-\mathrm{AgNO}_{3}-\mathrm{QACs}$ showed a significant $99.9999 \%$ antibacterial activity compared to AA ( $p<$ $0.001)$. No surviving bacteria could be detected on these materials after 1 h of contact. Similar results were observed after 1, 2, and 3 rounds of immersions ( $\simeq 0 \mathrm{CFU}$ per surface, $p<0.001$ ). Following 4 and 5 rounds of immersion, the antibacterial activity of the AA$\mathrm{AgNO}_{3}-\mathrm{QACs}$ decreased slightly $\left(1.0 \times 10^{2} \mathrm{CFU}\right.$ per surface after 5 rounds), while still maintaining a great efficiency by eliminating $99.99 \%$ of bacteria. However, after 6,7 , and 8 rounds of immersion, the $\mathrm{AA}-\mathrm{AgNO}_{3}-\mathrm{QACs}$ surfaces gradually lost their antibacterial activity $\left(2.4 \times 10^{3}, 2.7 \times 10^{4}, 6.7 \times 10^{4}\right.$ CFU per surface, respectively) (Fig. 8). After 9 and 10 immersions, the materials completely lost their antibacterial properties and were comparable to the AA control $\left(6.2 \times 10^{5}\right.$ and $9.0 \times 10^{5} \mathrm{CFU}$ per surface; Fig. 8). This phenomenon is likely explained by the fact

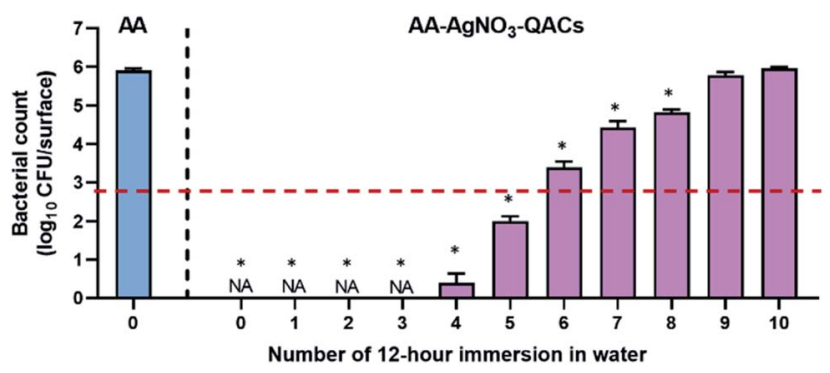

Fig. 8 Impact of successive $12 \mathrm{~h}$ immersions in sterile water on the antibacterial properties of materials on $S$. aureus. The reference of 99.9\% antibacterial activity is indicated by the dotted red line. Results are means $\pm \operatorname{SEM}(n=3 ; N=12)$. Statistical effect compared to AA: ${ }^{*} p$ $<0.0001$. NA: no bacteria counted. that following immersion in water, the antibacterial QACs compounds were quickly released from the materials (AA-QACs or $\mathrm{AA}-\mathrm{AgNO}_{3}-\mathrm{QACs}$ ), as demonstrated in Fig. 2, and several consecutive immersions led to complete emptying of the nanopores. These results demonstrate that AA materials impregnated with QACs would not be recommended for applications where surfaces are frequently or constantly immersed in a liquid environment (e.g., baths, toilets, taps, etc.).

Altogether, our results demonstrate the need to define the appropriate applications and the most suitable and least damaging sanitation protocols for antibacterial materials in order to assess the durability of their antibacterial properties. ${ }^{\mathbf{1 1 6 , 1 1 7}}$ Along the same line, most international standards are in the process of being updated since they do not currently assess the time and cleaning products' impacts on the antibacterial properties of materials, and they do not consider the conditions of use.

\section{Conclusions}

One of the biggest challenges in the design of antibacterial high-touch surfaces is the sustainable conservation of their properties. The antibacterial properties of materials (inherent material activity or surface modifications) fluctuate depending on the type of bacteria with which they interact, the typical surface wear (e.g., fouling), the conditions of their use (humidity, temperature, dry or liquid environment, etc.) and the cleaning and disinfection procedures. These parameters should always be properly characterized and considered when developing and evaluating their antibacterial properties. In this study, nanoporous AA-QACs surfaces demonstrated excellent and rapid antibacterial efficiency on a wide range of Grampositive and Gram-negative bacteria, independent of the presence of a capsule or antibiotic resistance. Although AA-QACs surfaces were not sporicidal, they nonetheless outperformed copper alloys, considered to be reference antibacterial materials. Furthermore, this high performance in short contact times has been demonstrated under conditions mimicking various surface contamination scenarios: liquid (swab), humid (contaminated gel) and dry (contaminated filter). Importantly, these materials must be used in dry environments (not submerged in liquids) and should be cleaned with QACs-based solutions to preserve their antibacterial properties. Hardanodized aluminum materials impregnated with QACs constitute a promising innovative strategy to prevent the transmission of pathogenic bacteria linked to the contaminated inert environment.

\section{Author contributions}

JJ and OD performed the experiments. JJ, OD, NF and LCF analyzed the data. JJ, OD GS, XGC, NF and LCF designed the study and experiments. MAG provided the materials. JJ, NF and LCF wrote the manuscript and all authors revised and approved the final version. 


\section{Conflicts of interest}

The authors declare that they have no known competing financial interests or personal relationships that could have appeared to influence the work reported in this paper.

\section{Acknowledgements}

This research was supported by a Rio Tinto graduate scholarship and by a Fonds de recherche du Québec - Nature et technologies (FRQNT) doctoral research scholarship (\#304067) to JJ, as well as a team grant from FRQNT Programme de recherche en partenariat sur la production et la transformation de l'aluminium (\#2018-LU-210883). The authors would like to thank Maxime Dumont (A3 Surfaces) who performed the anodization and impregnation process, and Jean-Luc Bernier for insightful discussions during the project.

\section{References}

1 World Health Organization, Report on the Burden of Endemic Health Care-Associated Infection Worldwide, WHO Libr. Cat. Data, 2012, pp. 1-25.

2 World Health Organization, Plan d'action mondial pour combattre la résistance aux antimicrobiens, WHO Libr. Cat. Data, 2016, pp. 1-32.

3 Interagency Coordination Group on Antimicrobial Resistance, No time to Wait: Securing the Future from Drug-Resistant Infections, Rep. to Secr. Gen. United Nations, 2019, vol. 1, pp. 1-28.

4 U.S. Department of Health and Human Services, Antibiotic Resistance Threats in the United States, CDC Centers Dis. Control Precention, 2019, vol. 1, pp. 1-150.

5 World Bank Group, Drug-Resistant Infections: A Threat to Our Economic Future, 2017.

6 G. Suleyman, G. Alangaden and A. C. Bardossy, The Role of Environmental Contamination in the Transmission of Nosocomial Pathogens and Healthcare-Associated Infections, Curr. Infect. Dis. Rep., 2018, 20, 1-11.

7 J. A. Otter and G. L. French, The Role Played by Contaminated Surfaces in the Transmission of Nosocomial Pathogens, Infect. Control Hosp. Epidemiol., 2011, 32, 687-699.

8 T. Z. Wang, M. S. Simon, L. F. Westblade, L. Saiman, E. Y. Furuya and D. P. Calfee, Quantitative characterization of high-touch surfaces in emergency departments and hemodialysis facilities, Infect. Control Hosp. Epidemiol., 2021, 42, 474-476.

9 M. M. Querido, L. Aguiar, P. Neves, C. C. Pereira and J. P. Teixeira, Self-disinfecting surfaces and infection control, Colloids Surf., B, 2019, 178, 8-21.

10 B. C. Sousa, C. J. Massar, M. A. Gleason and D. L. Cote, On the emergence of antibacterial and antiviral copper cold spray coatings, J. Biol. Eng., 2021, 15, 1-15.

11 V. M. Villapún, L. G. Dover, A. Cross, S. González and C. R. Arciola, Antibacterial Metallic Touch Surfaces, Materials, 2016, 9, 736.
12 D. J. Weber and W. A. Rutala, American Journal of Infection Control Self-disinfecting surfaces: Review of current methodologies and future prospects, Am. J. Infect. Control, 2013, 41, 31-35.

13 C. Espírito Santo, E. Wen Lam, C. G. Elowsky, D. Quaranta, D. W. Domaille, C. J. Chang and G. Grass, Bacterial Killing by Dry Metallic Copper Surfaces, Appl. Environ. Microbiol., 2011, 77, 794-802.

14 J. J. Green, K. Drye, W. Llp and K. Street, Antimicrobial Copper Alloys - Group I (EPA Reg. No. 82012-1) and Associated Fabricated Products, Washington, D.C, 2014.

15 M. Colin, F. Klingelschmitt, E. Charpentier, J. Josse, L. Kanagaratnam, C. De Champs and S. C. Gangloff, Copper alloy touch surfaces in healthcare facilities: An effective solution to prevent bacterial spreading, Materials, 2018, 11, 1-12.

16 D. Mitra, E. T. Kang and K. G. Neoh, Antimicrobial CopperBased Materials and Coatings: Potential Multifaceted Biomedical Applications, ACS Appl. Mater. Interfaces, 2020, 12, 21159-21182.

17 F. Pietsch, A. J. O'Neill, A. Ivask, H. Jenssen, J. Inkinen, A. Kahru, M. Ahonen and F. Schreiber, Selection of resistance by antimicrobial coatings in the healthcare setting, J. Hosp. Infect., 2020, 106, 115-125.

18 S. J. Dancer, How Much Impact Do Antimicrobial Surfaces Really Have on Healthcare-acquired Infection?, Clin. Infect. Dis., 2020, 71, 1814-1816.

$19 \mathrm{~J}$. O'Gorman and H. Humphreys, Application of copper to prevent and control infection. Where are we now?, J. Hosp. Infect., 2012, 81, 217-223.

20 M. P. Muller, C. MacDougall, M. Lim, I. Armstrong, A. Bialachowski, S. Callery, W. Ciccotelli, M. Cividino, J. Dennis, S. Hota, G. Garber, J. Johnstone, K. Katz, A. McGeer, V. Nankoosingh, C. Richard and M. Vearncombe, Antimicrobial surfaces to prevent healthcare-associated infections: A systematic review, $J$. Hosp. Infect., 2016, 92, 7-13.

21 I. Pineda, R. Hubbard and F. Rodriguez, The role of copper surfaces in reducing the incidence of healthcare-associated infections: A systematic review and meta-analysis, Can. J. Infect. Control, 2017, 32, 13-24.

22 E. M. Hetrick and M. H. Schoenfisch, Reducing implantrelated infections: active release strategies, Chem. Soc. Rev., 2006, 35, 780.

23 M. Zilberman and J. J. Elsner, Antibiotic-eluting medical devices for various applications, J. Controlled Release, 2008, 130, 202-215.

24 A. Tripathy, P. Sen, B. Su and W. H. Briscoe, Natural and bioinspired nanostructured bactericidal surfaces, Adv. Colloid Interface Sci., 2017, 248, 85-104.

25 E. P. Ivanova, J. Hasan, H. K. Webb, V. K. Truong, G. S. Watson, J. A. Watson, V. A. Baulin, S. Pogodin, J. Y. Wang, M. J. Tobin, C. Löbbe and R. J. Crawford, Natural bactericidal surfaces: Mechanical rupture of pseudomonas aeruginosa cells by cicada wings, Small, 2012, 8, 2489-2494. 
26 X. He, X. Suo, X. Bai, C. Yuan and H. Li, Functionalizing aluminum substrata by quaternary ammonium for antifouling performances, Appl. Surf. Sci., 2018, 440, 300307.

27 H. Agbe, D. K. Sarkar, X. G. Chen, N. Faucheux, G. Soucy and J. L. Bernier, Silver-Polymethylhydrosiloxane Nanocomposite Coating on Anodized Aluminum with Superhydrophobic and Antibacterial Properties, ACS Appl. Bio Mater., 2020, 3, 4062-4073.

28 H. Agbe, D. K. Sarkar and X. G. Chen, Tunable superhydrophobic aluminum surfaces with antibiofouling and antibacterial properties, Coatings, 2020, 10, 1-10.

29 C. P. Gerba, Quaternary Ammonium Biocides: Efficacy in Application, Appl. Environ. Microbiol., 2015, 81, 464-469.

30 G. Mcdonnell and A. D. Russell, Antiseptics and Disinfectants: Activity, Action, and Resistance, Clin. Microbiol. Rev., 1999, 12, 147-179.

31 D. Druvari, N. D. Koromilas, G. Ch Lainioti, G. Bokias, G. Vasilopoulos, A. Vantarakis, I. Baras, N. Dourala and J. K. Kallitsis, Polymeric Quaternary AmmoniumContaining Coatings with Potential Dual Contact-Based and Release-Based Antimicrobial Activity, ACS Appl. Mater. Interfaces, 2016, 8, 35593-35605.

32 M. C. Jennings, K. P. C. Minbiole and W. M. Wuest, Quaternary Ammonium Compounds: An Antimicrobial Mainstay and Platform for Innovation to Address Bacterial Resistance, ACS Infect. Dis., 2015, 1, 288-303.

33 S. Bai, X. Li, Y. Zhao, L. Ren and X. Yuan, Antifogging/ Antibacterial Coatings Constructed by NHydroxyethylacrylamide and Quaternary AmmoniumContaining Copolymers, ACS Appl. Mater. Interfaces, 2020, 12, 12305-12316.

$34 \mathrm{~W}$. A. Rutala and D. J. Weber, New disinfection and sterilization methods, Emerging Infect. Dis., 2001, 7, 348353.

35 N. Silvestry-Rodriguez, E. E. Sicairos-Ruelas, C. P. Gerba and K. R. Bright, Silver as a disinfectant, Rev. Environ. Contam. Toxicol., 2007, 191, 23-45.

36 A. Valiei, M. Okshevsky, N. Lin and N. Tufenkji, Anodized Aluminum with Nanoholes Impregnated with Quaternary Ammonium Compounds Can Kill Pathogenic Bacteria within Seconds of Contact, ACS Appl. Mater. Interfaces, 2018, 10, 41207-41214.

37 S. Liu, J. Tian and W. Zhang, Fabrication and application of nanoporous anodic aluminum oxide: A review, Nanotechnology, 2021, 32, 1-20.

38 M. Dumont, J. Lambert, G. Leblanc, M. Lambert, M. Lavoie, J. P. Collard, M. Auclair-Gilbert, S. Gagnon, Anodized biocidal metallic material, process for making the material and method for reactivating the material, WO2021/113972A1, 2021.

39 Copper Development Association Inc., Standard Designation for Wrought Copper Alloy, https:/www.copper.org/resources/ properties/db/datasheets/all-alloys.pdf, accessed 11 January 2021.
40 J. E. Galan and R. O. Y. Curtiss, Distribution of the invA, -B, -C, and -D Genes of Salmonella typhimurium among Other Salmonella Serovars: invA Mutants of Salmonella typhi Are Deficient for Entry into Mammalian Cells, Infect. Immun., 1991, 59, 2901-2908.

41 A. F. Gaudy, F. Abu-Niaaj and E. T. Gaudy, Statistical study of the spot-plate technique for viable-cell counts, Appl. Microbiol., 1963, 11, 305-309.

42 J. Wang, M. Woo and C. Yan, Spot Plating Assay for the Determination of Survival and Plating Efficiency of Escherichia coli in sub-MIC Levels of Antibiotics, JEMI Methods, 2017, 1, 26-29.

43 International Organization for Standardization, ISO 22196: Measurement of antibacterial activity on plastics and other non-porous surfaces, Int. Stand., 2011, 1-15.

44 Food and Drug Administration, Pharmaceutical Microbiology Manual, Off. Regul. Sci., 2020, vol. 2, pp. 1-96.

45 P. J. Caspers, G. W. Lucassen, E. A. Carter, H. A. Bruining and G. J. Puppels, In vivo confocal Raman microspectroscopy of the skin: Noninvasive determination of molecular concentration profiles, J. Invest. Dermatol., 2001, 116, 434-442.

46 F. Hizal, N. Rungraeng, J. Lee, S. Jun, H. J. Busscher, H. C. Van Der Mei and C. Choi, Nanoengineered Superhydrophobic Surfaces of Aluminum with Extremely Low Bacterial Adhesivity, ACS Appl. Mater. Interfaces, 2017, 9, 12118-12129.

47 D. Wojcieszak, M. Mazur, D. Kaczmarek, P. Mazur, B. Szponar, J. Domaradzki and L. Kepinski, Influence of the surface properties on bactericidal and fungicidal activity of magnetron sputtered $\mathrm{Ti}-\mathrm{Ag}$ and $\mathrm{Nb}-\mathrm{Ag}$ thin films, Mater. Sci. Eng., C, 2016, 62, 86-95.

48 J. G. Buijnsters, R. Zhong, N. Tsyntsaru and J. Celis, Surface Wettability of Macroporous Anodized Aluminum Oxide, ACS Appl. Mater. Interfaces, 2013, 5, 3224-3233.

49 Y. Li, S. Yang, Y. Chen and D. Zhang, Hydrophobic and antifouling performance of surface on parabolic morphology, Int. J. Environ. Res. Public Health, 2020, 17, 644-655.

50 C. Ran, G. Ding, W. Liu, Y. Deng and W. Hou, Wetting on Nanoporous Alumina Surface: Transition between Wenzel and Cassie States Controlled by Surface Structure, Langmiur, 2008, 24, 9952-9955.

51 S. P. Rodrigues, C. F. A. Alves, A. Cavaleiro and S. Carvalho, Applied Surface Science Water and oil wettability of anodized 6016 aluminum alloy surface, Appl. Surf. Sci., 2015, 422, 430-442.

52 C. Jeong and H. Ji, Single-Step Direct Fabrication of Pillaron-Pore Hybrid Nanostructures in Anodizing Aluminum for Superior Superhydrophobic Efficiency, ACS Appl. Mater. Interfaces, 2012, 4, 842-848.

53 J. Zang, S. Yu, G. Zhu and X. Zhou, Fabrication of superhydrophobic surface on aluminum alloy 6061 by a facile and effective anodic oxidation method, Surf. Coat. Technol., 2019, 370, 125078.

54 C. Jeong and H. Ji, Systematic control of anodic aluminum oxide nanostructures for enhancing the 
superhydrophobicity of 5052 aluminum alloy, Materials, 2019, 12, 3231-3242.

55 S. U. Ofoegbu and F. A. O. Fernandes, The Sealing Step in Aluminum Anodizing: A Focus on Sustainable Strategies for Enhancing Both Energy Efficiency and Corrosion Resistance, Coatings, 2020, 10, 1-55.

56 C. P. Gerba, Quaternary Ammonium Biocides: Efficacy in Application, Appl. Environ. Microbiol., 2015, 81, 464-469.

57 F. Bureš, Quaternary Ammonium Compounds: Simple in Structure, Complex in Application, Top. Curr. Chem., 2019, 377, 1-21.

58 J. Song, H. Kong and J. Jang, Bacterial adhesion inhibition of the quaternary ammonium functionalized silica nanoparticles, Colloids Surf., B, 2011, 82, 651-656.

59 J. Pant, J. Gao, M. J. Goudie, S. Hopkins, J. Locklin and H. Handaa, A Multi-defense Strategy: Enhancing Bactericidal Activity of a Medical Grade Polymer with a Nitric Oxide Donor and Surface immobilized Quaternary Ammonium Compound, Acta Biomater., 2017, 58, 421-431.

60 D. Wojcieszak, D. Kaczmarek, A. Antosiak, M. Mazur, Z. Rybak, A. Rusak, M. Osekowska, A. Poniedzialek, A. Gamian and B. Szponar, Influence of $\mathrm{Cu}-\mathrm{Ti}$ thin film surface properties on antimicrobial activity and viability of living cells, Mater. Sci. Eng., C, 2015, 56, 48-56.

61 F. Keller, M. S. Hunter and D. L. Robinson, Structural Features of oxide coating on Aluminium, J. Electrochem. Soc., 1953, 100, 411-419.

62 P. G. Sheasby and R. Pinner, The surface Treatment and Finishing of Aluminium and its Alloys, Finish. Publ. Ltd., ASM Int., 6th edition, 2001, pp. 327-400, 405-410, 744818 and 985.

63 H. Takahashi, in ASM Handbook Corrosion: Fundamentals, Testing, and Protection, 2003, pp. 736-740.

64 R. Zhang, K. Jiang and G. Ding, Surface morphology control on porous anodic alumina in phosphoric acid, Thin Solid Films, 2010, 518, 3797-3800.

65 M. Porta-i-Batalla, E. Xifré-Pérez, C. Eckstein, J. FerréBorrull and L. F. Marsal, 3D nanoporous anodic alumina structures for sustained drug release, Nanomaterials, 2017, 7, 227-239.

66 S. McGinty, T. T. N. Vo, M. Meere, S. McKee and C. McCormick, Some design considerations for polymerfree drug-eluting stents: A mathematical approach, Acta Biomater., 2015, 18, 213-225.

67 S. Y. Liau, D. C. Read, W. J. Pugh, J. R. Furr and A. D. Russell, Interaction of silver nitrate with readily identifiable groups: Relationship to the antibacterial action of silver ions, Lett. Appl. Microbiol., 1997, 25, 279283.

68 P. Singh, Y. J. Kim, H. Singh, C. Wang, K. H. Hwang, M. E. A. Farh and D. C. Yang, Biosynthesis, characterization, and antimicrobial applications of silver nanoparticles, Int. J. Nanomed., 2015, 10, 2567-2577.

69 C. Greulich, D. Braun, A. Peetsch, J. Diendorf, B. Siebers, M. Epple and M. Köller, The toxic effect of silver ions and silver nanoparticles towards bacteria and human cells occurs in the same concentration range, $R S C A d v ., 2012$, 2, 6981-6987.

70 G. Mulley, A. T. A. Jenkins and N. R. Waterfield, Inactivation of the antibacterial and cytotoxic properties of silver ions by biologically relevant compounds, PLoS One, 2014, 9, 2-10.

71 E. D. Cavassin, L. F. P. de Figueiredo, J. P. Otoch, M. M. Seckler, R. A. de Oliveira, F. F. Franco, V. S. Marangoni, V. Zucolotto, A. S. S. Levin and S. F. Costa, Comparison of methods to detect the in vitro activity of silver nanoparticles (AgNP) against multidrug resistant bacteria, J. Nanobiotechnol., 2015, 13, 1-16.

72 C. Krishnaraj, E. G. Jagan, S. Rajasekar, P. Selvakumar, P. T. Kalaichelvan and N. Mohan, Synthesis of silver nanoparticles using Acalypha indica leaf extracts and its antibacterial activity against water borne pathogens, Colloids Surf., B, 2010, 76, 50-56.

$73 \mathrm{~S}$. Wessels and H. Ingmer, Modes of action of three disinfectant active substances: A review, Regul. Toxicol. Pharmacol., 2013, 67, 456-467.

74 T. Ikeda, H. Hirayama, H. Yamaguchi, S. Tazuke and M. Watanabe, Polycationic biocides with pendant active groups: Molecular weight dependence of antibacterial activity, Antimicrob. Agents Chemother., 1986, 30, 132-136.

75 J. He, E. Söderling, P. K. Vallittu and L. V. J. Lassila, Investigation of double bond conversion, mechanical properties, and antibacterial activity of dental resins with different alkyl chain length quaternary ammonium methacrylate monomers (QAM), J. Biomater. Sci., Polym. Ed., 2013, 24, 565-573.

76 M. Kong, X. G. Chen, K. Xing and H. J. Park, Antimicrobial properties of chitosan and mode of action: A state of the art review, Int. J. Food Microbiol., 2010, 144, 51-63.

77 P. Gilbert and L. E. Moore, Cationic antiseptics: Diversity of action under a common epithet, J. Appl. Microbiol., 2005, 99, 703-715.

78 M. Tischer, G. Pradel, K. Ohlsen and U. Holzgrabe, Quaternary ammonium salts and their antimicrobial potential: Targets or nonspecific interactions?, ChemMedChem, 2012, 7, 22-31.

79 B. Gottenbos, D. W. Grijpma, H. C. Van Der Mei, J. Feijen and H. J. Busscher, Antimicrobial effects of positively charged surfaces on adhering Gram-positive and Gramnegative bacteria, J. Antimicrob. Chemother., 2001, 48, 7-13.

80 A. Cavallaro, A. Mierczynska, M. Barton, P. Majewski and K. Vasilev, Influence of immobilized quaternary ammonium group surface density on antimicrobial efficacy and cytotoxicity, Biofouling, 2016, 32, 13-24.

81 D. R. Perinelli, D. Petrelli, D. Vllasaliu, L. A. Vitali, G. Bonacucina, M. Cespi, G. Giorgioni and G. F. Palmieri, Quaternary ammonium leucine-based surfactants: The effect of a benzyl group on physicochemical properties and antimicrobial activity, Pharmaceutics, 2019, 11, 287288.

82 Y. Jiao, L. Niu, S. Ma, J. Li, F. R. Tay and J. Chen, Progress in Polymer Science Quaternary ammonium-based biomedical materials: State-of-the-art, toxicological aspects and antimicrobial resistance, Prog. Polym. Sci., 2017, 71, 53-90. 
83 Y. Jiao, L. Niu, S. Ma, J. Li, F. R. Tay and J. Chen, Quaternary ammonium-based biomedical materials: State-of-the-art, toxicological aspects and antimicrobial resistance, Prog. Polym. Sci., 2017, 71, 53-90.

84 C. J. Ioannou, G. W. Hanlon and S. P. Denyer, Action of disinfectant quaternary ammonium compounds against Staphylococcus aureus, Antimicrob. Agents Chemother., 2007, 51, 296-306.

85 Y. H. Xiao, J. H. Chen, M. Fang, X. D. Xing, H. Wang, Y. J. Wang and F. Li, Antibacterial effects of three experimental quaternary ammonium salt (QAS) monomers on bacteria associated with oral infections, $J$. Oral Sci., 2008, 50, 323-327.

86 J. Li, Z. Sha, W. Zhang, F. Tao and P. Yang, Preparation and antibacterial properties of gelatin grafted with an epoxy silicone quaternary ammonium salt, J. Biomater. Sci., Polym. Ed., 2016, 27, 1017-1028.

87 D. R. Perinelli, D. Petrelli, L. A. Vitali, D. Vllasaliu, M. Cespi, G. Giorgioni, E. Elmowafy, G. Bonacucina and G. F. Palmieri, Quaternary ammonium surfactants derived from leucine and methionine: Novel challenging surface active molecules with antimicrobial activity, J. Mol. Liq., 2019, 283, 249-256.

88 A. D. Russell, W. B. Hugo and G. A. J. Ayliffe's, Principles and Practice of Disinfection, Preservation \& Sterilization, John Wiley, Hoboken, USA, 2008.

89 A. Muñoz-Bonilla and M. Fernández-García, Polymeric materials with antimicrobial activity, Prog. Polym. Sci., 2012, 37, 281-339.

90 B. Hota, Contamination, disinfection, and crosscolonization: Are hospital surfaces reservoirs for nosocomial infection?, Clin. Infect. Dis., 2004, 39, 11821189.

91 D. J. Weber, W. A. Rutala, M. B. Miller, K. Huslage and E. Sickbert-Bennett, Role of hospital surfaces in the transmission of emerging health care-associated pathogens: Norovirus, Clostridium difficile, and Acinetobacter species, Am. J. Infect. Control, 2010, 38, S25S33.

92 D. J. Weber, D. Anderson and W. A. Rutala, The role of the surface environment in healthcare-associated infections, Curr. Opin. Infect. Dis., 2013, 26, 338-344.

93 S. L. Warnes, S. M. Green, H. T. Michels and C. W. Keevil, Biocidal efficacy of copper alloys against pathogenic enterococci involves degradation of genomic and plasmid DNAs, Appl. Environ. Microbiol., 2010, 76, 5390-5401.

94 A. Różzańska, A. Chmielarczyk, D. Romaniszyn, A. SrokaOleksiak, M. Bulanda, M. Walkowicz, P. Osuch and T. Knych, Antimicrobial properties of selected copper alloys on Staphylococcus aureus and Escherichia coli in different simulations of environmental conditions: With vs. without organic contamination, Int. J. Environ. Res. Public Health, 2017, 14, 813-838.

95 L. Weaver, H. T. Michels and C. W. Keevil, Survival of Clostridium difficile on copper and steel: futuristic options for hospital hygiene, J. Hosp. Infect., 2008, 68, 145-151.
96 M. K. Paczosa and J. Mecsas, Klebsiella pneumoniae: Going on the Offense with a Strong Defense, Microbiol. Mol. Biol. Rev., 2016, 80, 629-661.

97 C. Opoku-Temeng, S. D. Kobayashi and F. R. DeLeo, Klebsiella pneumoniae capsule polysaccharide as a target for therapeutics and vaccines, Comput. Struct. Biotechnol. J., 2019, 17, 1360-1366.

98 M. A. Bachman, P. Breen, V. Deornellas, Q. Mu, L. Zhao, W. Wu, J. D. Cavalcoli and H. L. T. Mobley, Genome-wide identification of Klebsiella pneumoniae fitness genes during lung infection, mBio, 2015, 6, 1-9.

99 M. Rosenberg, H. Vija, A. Kahru, C. Keevil and A. Ivask, Rapid in situ assessment of $\mathrm{Cu}$-ion mediated effects and antibacterial efficacy of copper surfaces, Sci. Rep., 2018, 8, 1-12.

100 C. E. Santo, E. W. Lam, C. G. Elowsky, D. Quaranta, D. W. Domaille, C. J. Chang and G. Grass, Bacterial killing by dry metallic copper surfaces, Appl. Environ. Microbiol., 2011, 77, 794-802.

101 Durham University, Metal-Related Antimicrobials Showcase Event, http://www.ncbi.nlm.nih.gov/pubmed/28773856, accessed 26 April 2019.

102 V. C. C. Cheng, P. H. Chau, W. M. Lee, S. K. Y. Ho, D. W. Y. Lee, S. Y. C. So, S. C. Y. Wong, J. W. M. Tai and K. Y. Yuen, Hand-touch contact assessment of high-touch and mutual-touch surfaces among healthcare workers, patients, and visitors, J. Hosp. Infect., 2015, 90, 220-225.

103 United States Environmental Protection Agency (US EPA), Protocol for the evaluation of bactericidal activity of hard, non-porous copper/copper-alloy surfaces, 02/03/15, 2015, pp. 5-13.

104 C. L. Silva, D. Topgaard, V. Kocherbitov, J. J. S. Sousa, A. A. C. C. Pais and E. Sparr, Stratum corneum hydration: Phase transformations and mobility in stratum corneum, extracted lipids and isolated corneocytes, Biochim. Biophys. Acta, Biomembr., 2007, 1768, 2647-2659.

105 A. L. Byrd, Y. Belkaid and J. A. Segre, The human skin microbiome, Nat. Rev. Microbiol., 2018, 16, 143-155.

106 D. D. Balci, N. Duran, B. Ozer, R. Gunesacar, Y. Onlen and J. Z. Yenin, High prevalence of Staphylococcus aureus cultivation and superantigen production in patients with psoriasis, Eur. J. Dermatol., 2009, 19, 238-242.

$107 \mathrm{H}$. Brüggemann, Insights in the pathogenic potential of Propionibacterium acnes from its complete genome, Semin. Cutaneous Med. Surg., 2005, 24, 67-72.

108 INSPQ, COVID-19: Nettoyage et désinfection de surfaces résidentiels et les lieux publics concernant le virus, Inst. Natl. Santé Publique du Québec, 2020, pp. 1-9.

109 R. S. Boethling and D. G. Lynch, in Detergents, Springer Berlin Heidelberg, Berlin, Heidelberg, 1992, pp. 145-177.

110 U.S. EPA: U.S. Environmental Protection Agency, Reregistration Eligibility Decision (RED) for Alkyl Dimethyl Benzyl Ammonium Chloride (ADBAC), 2006.

111 U.S. EPA: U.S. Environmental Protection Agency, Reregistration Eligibility Decision for Aliphatic Alkyl Quaternaries (DDAC), 2006. 
112 J. M. Campos-Martin, G. Blanco-Brieva and J. L. G. Fierro, Hydrogen peroxide synthesis: An outlook beyond the anthraquinone process, Angew. Chem., Int. Ed., 2006, 45, 6962-6984.

113 T. Du, A. Vijayakumar and V. Desai, Effect of hydrogen peroxide on oxidation of copper in CMP slurries containing glycine and $\mathrm{Cu}$ ions, Electrochim. Acta, 2004, 49, 4505-4512.

114 H. Jo, S. Lee, D. Kim and J. Lee, Low temperature sealing of anodized aluminum alloy for enhancing corrosion resistance, Materials, 2020, 13, 1-12.
115 S. Wernick, R. Pinner and P. Sheasby, The Surface Treatments of Aluminium and Its Alloys, OH, USA, 5th edn, 1987.

116 C. Adlhart, J. Verran, N. F. Azevedo, H. Olmez, M. M. Keinänen-Toivola, I. Gouveia, L. F. Melo and F. Crijns, Surface modifications for antimicrobial effects in the healthcare setting: a critical overview, J. Hosp. Infect., 2018, 99, 239-249.

117 M. Ojeil, C. Jermann, J. Holah, S. P. Denyer and J. Y. Maillard, Evaluation of new in vitro efficacy test for antimicrobial surface activity reflecting UK hospital conditions, J. Hosp. Infect., 2013, 85, 274-281. 